Title:

\title{
Supplier-customer engagement for collaborative innovation using video conferencing: A study of SMEs
}

Hardwick, Jialin \& Anderson, Alistair R. (2019). Supplier-customer engagement for collaborative innovation using video conferencing: A study of SMEs. Industrial Marketing Management, In press, available at https://www.sciencedirect.com/science/article/abs/pii/\$0019850116303285.

\begin{abstract}
Co-creation of innovation, as transcending perspective of marketing, is of growing interest in recent years. Developing new products through collaboration is recognized as beneficial to suppliers as well as customers. Businesses face challenges as to how to build and develop close and long-lasting collaborative relationships for innovation success. Owners/managers need to know about which platform to use appropriate for different engagement aspects in the relationship development. The advancement in virtual technology may offer new platforms in enabling customer engagement apart from traditional platforms. This study explores how suppliers and customers are engaged in videoconferencing in their engagement processes in collaborative innovation. Based on an empirical study of in-depth interviews with seventeen owners/managers in biotech SMEs (Small and Medium Sized Enterprise), from a supplier's perspective it reveals that the engagement is processual and has two dimensions for the successful collaborative relationships. Videoconferencing is a platform for engagement when distance is a barrier, it's used in both dimensions of the engagement, and to facilitate cognition and support affect which help form and cement trusting relationships. The authors explain the process of videoconference engagement by a ladder of engagement model through social networking theory in building and applying social capital.
\end{abstract}

\section{Keywords}

Co-creation, Innovation, Supplier-customer engagement, Supplier-customer relationships, Virtual platform, Videoconference, SMEs (small and medium-sized enterprise), Biotechnology industry, High-tech 


\section{Introduction}

We are interested in establishing how customer engagement is furthered by videoconferencing (VC). Understanding engagement as representing a particular close relationship between supplier and customers, we focus on collaboration for co-creating innovative products where the customer's engagement creates the conditions for successful co-creation. This focus offers a theoretically valuable example of engagement process for analysis. Co-creation and engagement share common characteristics such as building on interactive experiences (Conduit and Chen, 2017) with co-creation a transcending perspective of marketing. Whilst engagement is increasingly recognised as important for brand management in B2C markets, less is known about engagement in B2B markets (Gambetti and Graffigna, 2010; Conduit and Chen, 2017) at a micro level. We believe that exploring engagement in the $\mathrm{B} 2 \mathrm{~B}$ relationship of supplier-customer collaboration in SMEs (Small and Medium Sized Enterprises) may be useful for a better understanding of practices. We are specifically interested in how one mode of engagement (Phillips and MacQuarrie, 2010), videoconferencing enables engagement (Hollebeek et al, 2016a), allowing us to better understand the nature, processes and dynamics surrounding engagement-based relationships. Accordingly, we want to relate what has been described as the transformative power of virtual technology (Wendt \& Harris, 1996) that has changed the interactive experiences in supplier-customer relationships (Brodie et al., 2013) with the new dominant logic of marketing, engagement.

\section{The research problem and context}

Videoconferencing is part of the new wave of communication technologies argued to have the potential to transform marketing communication; a "powerful platform for enabling collaborative innovation with customers" (Sawhney et al., 2005: 2). As a collaborative effort, the features of engagement's enhanced involvement used to require physical and social proximity (Geldes et al., 2017). More recently, this historical context of physical proximity to customers may be overcome by this global medium with unprecedented reach. However, social proximity may be more problematic for engagement. Vargo and Lusch (2016) describe how being 'connected virtually' allows resource integration, a critical element for co-creation. Anderson and Li (2014) describe how 'synergic' collaborations create value, or as Grönroos and Voima (2013) propose, 'value formation' by integrating knowledge. Furthermore, the value proposition is not determined by the supplier alone, but jointly by suppliers and customers (Macdonald et al., 2016). Moreover, Kleinaltenkamp et al. (2017) discussing usage centres, explain how value generation is co-created. Ostrom et al. (2010) point out the importance of contexts in understanding and coordinating value creation in actors, networked and collaborative firms. We thus consider that our research setting, B2B engagement for collaboration by SMEs, offers an interesting exploratory context.

Collaborating for innovation provides an important example for understanding engagement (Sawheny et al, 2005). Such deeper collaboration requires engagement to enable sharing of 
tacit knowledge. Moreover, shared interest in value creation characterises the strong links in engagement needed to facilitate the trust required in close collaboration. Consequently, the engagement constructs of commitment, involvement and trust (Bowden, 2009) characterise effective collaborative relationships. Our research problem is that research results about the effectiveness of ICT for engagement are ambiguous and we question if context has played a role in the equivocal results. For example, B2B is different from $\mathrm{B} 2 \mathrm{C}$ and the changing dynamics of the B2B are reshaping marketplaces (Wiersema, 2013). Moreover, the SME context is simpler, making it easier to observe processes than the context of large firms which dominates the literature (Anderson et al, 2016). We are thus able to examine how well, and in what ways, VC works in furthering engagement. Our contribution is a finer grained account of engagement as a process in SMEs. We offer a theoretical model, 'the engagement ladder', a process model which explains stages and the development of engagement for collaboration.

\section{Theoretical Framework}

Engagement is a relational concept. In contrast to transactional marketing exchanges, the focus is on human, rather than economic interactions. It can be distinguished as relational by the extent and continuity of trust and commitment (Morgan and Hunt, 1994). Engagement is about processes rather than events, and expands the domain of relationship marketing (Vivek et al, 2012). Although rooted in relationship marketing (Brodie et al, 2013), engagement takes customer involvement to a higher level. However, although it shares many attributes and processes (Ashley et al., 2011), engagement is not simply relationship marketing in the emperor's new clothes. Nonetheless, Gambetti and Graffigna (2010) suggest these similarities may have created muddled, all-inclusive conceptualisations, where similar concepts are used synonymously with engagement. Brodie et al. (2013) propose that the concept of engagement replaces traditional relational concepts, including involvement and participation. It represents the evolution of marketing from the marketing concept era to market orientation to relationship marketing (Sashi, 2012). Although there are a range of conceptualisations (Hollebeek et al., 2016b), Forrester Consulting (2008) describes customer engagement as creating deep connections. Consequently, the engagement concept has process, attributes and outcome elements which have been usefully employed in the networking literature. Brodie et al. (2013) suggest that engagement calls for integrating other theoretical perspectives. Thus, we draw on insights from analogous relational concepts. We will use social networking theory to explain how relationships develop by drawing on the concept of social capital.

Engagement, often applied as brand engagement, has cognitive, emotional and behavioural dimensions (Vernette \& Hamdi-Kidar, 2013) and social elements (Vivek et al., 2012) that resonate with the processes of networking and the attributes of social capital (Anderson \& Hardwick, 2017). Moreover, in new product development (NPD) in B2B markets, business partners seek long-term relationships rather than one-off exchange (Ferguson et al., 2016). Given the insights generated from the mature concepts of networking and social capital, we believe they may offer some explanatory purchase to help account for our research problem. For example, Gonzalez et al. (2014) argue that social capital is an important element in 
relationships, and we are especially interested in how engagement relationships are built. The role of social capital is played out in terms of trust and commitment, so that customer engagement (Brodie et al., 2013) could be understood in terms of social capital. The relationship of engagement is embedded in, endowed with shared social capital and yet also represents an outcome of social capital processes (Laud and Karpen, 2017). Moreover, social capital has two qualities, bridging and bonding (Anderson and Jack 2002; McKeever et al., 2015) that capture the process of connecting (Anderson et al, 2007) which Vivek et al. (2012) see as a definitive element in customer engagement. Similarly, Brodie et al. (2013) describe bonding in engagement. They also identify process elements of engagement, learning, sharing, advocating, socializing and co-development. Engagement thus not only shares characteristics with social capital but may be seen as a conceptual equivalent; running parallel, but in the more practical and directed marketing stream. Networking, in turn, informs us about the processes that create social capital.

Social networking theory has proven valuable in the analysis of supplier-customer relationships in SMEs co-creation for innovation (Larson, 1992, Fleming et al., 2007, Hardwick et al., 2013). Agrawal and Rahman's (2015) critical components in co-production, interaction and integration fit well with social networking. Networking theory could help explain behaviour in building and developing B2B organizational relationships because SMEs relationships intertwine with entrepreneurs' individual relationships, most formed through their engagement in networking (Miller et al., 2007). Differing from resource rich large firms, SMEs rely on trust and commitment to develop their organisational exchange relationships (Komulainen et al., 2006; Ruokonen et al., 2006). Our specific interest in customer engagement is in collaborations for developing new products. Here co-creation and engagement have related processes (Laud and Karpen, 2017) such as building on interactive experiences, iterative processes, and resultant mutual beneficial outcomes.

Imagining a ladder of increasing engagement, we conceive innovation collaborations on the highest rung. Indeed, for Conduit and Chen (2017), co-creation requires bridging concepts such as engagement to inform marketing practice. Anderson and Li (2014) describe as creating synergy between parties, whilst Gaddefors and Anderson (2009) see co-creation as the epitome of a marketing relationship. Accordingly, we believe that this theoretical framework is constructive; networking theory offers some explanatory leverage for processes of engagement, whilst social capital theory may help explain the outcomes of engaging. Insights about engagement have been somewhat restricted to engaging with brand, we believe that applying the concept in the close B2B relationship of customer supplier collaboration may be useful. The paper continues with our literature review.

\section{Literature review}

The review draws upon the literature on VC, co-creation of innovation and supplier-customer engagement. First examining how VC can enable engagement and media richness theories, we then consider co-creation and engagement, arguing this is a social process. 


\subsection{VC as an enabler of engagement}

VC differs from online marketing and conventional marketing channels that mainly aim at reaching customers for selling (Laroche et al., 2013, Kolter and Kellter, 2016) or social media that focus on connecting to customer communities through one-to-many (firm to consumers). In B2B markets, $\mathrm{VC}$ is a platform enabling interactions on one-to-one basis between business network partners (Roy et al., 2004; Vermeulen et al., 2005). Customer 'involvement' in engagement, especially in B2B, calls for frequent communication, so that VC may offer a time and cost saving alternative (Laud et al., 2015). However, virtual platforms vary in their technical capabilities for enabling actor interactions and different task performances (Dennis and Kinney, 1998). The literature indicates that VC may not be a complete substitute for meetings.

One theory that helps explain the limitations is Media Richness Theory (MRT) (Daft and Lengel, 1986; 1984). MRT focuses on platform capabilities for processing information and knowledge transfer. Media richness refers to the ability of a platform for dyads to transmit exchanges. The theory suggests different levels of interaction richness are achieved by various platforms. Face-face is the highest (visual, instant, multiple cues, personal nature), followed by VC (videoconferencing), AC (audioconferencing), telephone, written informal (letters); the lowest is written formal documents. MRT proposes that richer media is best for equivocal tasks with a high level of ambiguity such as explanation, clarification and negotiation, while lean platforms work for exchanging volumes of objective and quantitative data.

MRT is a widely applied theory of platforms effects (Thomas, 2013) and is informed by Short et al's (1976) social presence theory (SPT) (Dennis and Valacich, 1999) which highlights social presence as a critical factor influencing social effects on interactions. It proposes that nonverbal cues such as facial expressions and body gestures determine the interaction quality. Like MRT, SPT views richer platforms as more capable of conveying high social presences; face-face is the most appropriate for socialization because of the intimacy and immediacy generated (Short et al., 1976; Walther, 1995). VC is high in media richness among virtual platforms. Figure 1 proposes a ladder of media richness in platforms. 
Figure 1. Ladder of Interaction Richness
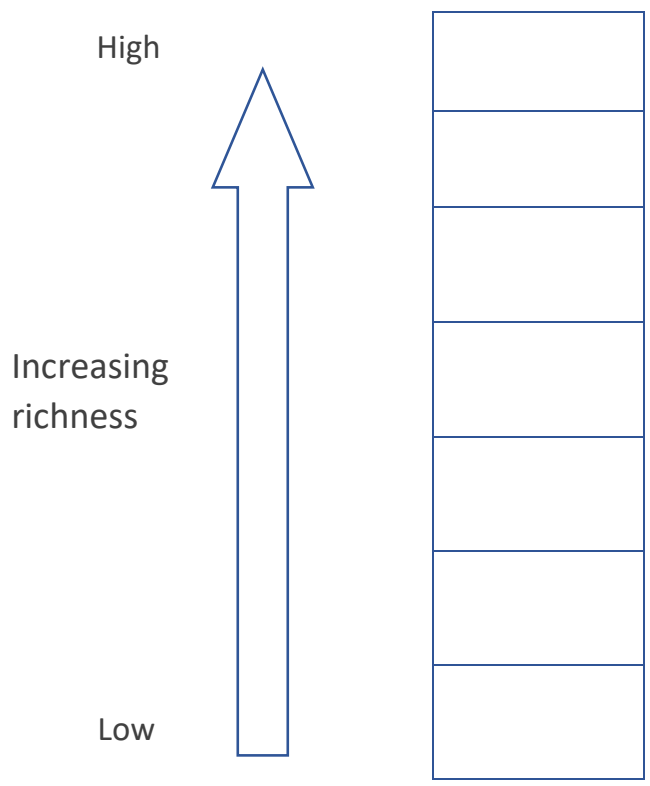

Face-face

Video conferencing

Audio conferencing

Telephones

\begin{tabular}{|c|}
\hline Emails \\
\hline \hline $\begin{array}{c}\text { Web-based tools (Blogs, } \\
\text { Wikis) }\end{array}$ \\
\hline $\begin{array}{c}\text { Brochures, reports, } \\
\text { memos }\end{array}$ \\
\hline
\end{tabular}

Source: Adapted from Daft and Lengel (1984) and Oke and Idiagbon-Oke (2010)

Although ranked as the second richest, VC has advantages over face-face, reducing expensive travel, making the best of available time, allowing dialogue with full two-way verbal communication between actors and pictorial objects (Carr et al., 2008; Mei-Ying and YungChih, 2014). However, compared to less rich platforms, VC is not always better. Rice and Case (1983) argued that in less rich media, the absence of non-verbal or social context cues such as appearance or accents avoids non-work distractions (Weisband and Atwater, 1999). Apart from Lengel and Daft (1988) who examined the techology itself, the increasing volume of VC literature investigated task performance (Van der Kleij et al., 2009; Caballer et al., 2005; Rosetti and Surynt, 1985), practice behaviours (Muhlfelder et al., 1999), factorial elements (Walther, 1995; Walther et al., 1994) and applications of VC in intra-organizational settings (Panteli and Dawson, 2001). Broadly, some aspects of communication worked well, but others less effectively. Those studies used survey methods (Rice and Case, 1983) or experiments (Weisband et al., 1995) that cannot explain the reasons for utility. In addition, most of the studied organisational settings were of larger organisations, although Mei-Ying and Yung-Chih (2014) studied actor engagement in VC in an SME and found the new generation of online communication, Microsoft Lync, integrated telephone, instant messaging and VC improved communication efficiency with clients and suppliers. Older studies also demonstrated communication improvements. Caballer et al. (2005) examining intellectual tasks in a student lab experiment concluded VC improved the affective responses and the efficiency of team interactions, whilst Numprasertchai and Igel (2004) found VC highly effective for 
encapsulating, transferring and integrating knowledge between researchers and external experts.

However, Oke and Idiagbon-Oke (2010) findings challenged this positive account. Examining VC and knowledge exchanges in inter-organisational innovation, no significant relationship was found. Similarly, Thomas (2013) investigating VC supplier-customer innovation businesses engagement found no benefit. However, Kawakami et al.'s (2011) findings were interesting; VC achieved effects similar to face-face meetings in actor engagement. However VC was ineffective for complicated conversations because it could not convey nuances of feelings. The usefulness of VC in engagement thus exhibits inconsistent utility (Walther, 1995) for fostering engagement. Whilst studies demonstrate both pros and cons of the technology (Thomas, 2013), challenges remain in comparing results. The research methods varied (Walther, 1995); different contexts and different relationships also affected how VC operates. Indeed Carr et al. (2008) argues that considering technology as a 'black box', omitting the relational and processual context in which the actors are embedded, may produce a misleading picture. Effective actor interactions using VC require the appropriate use of both platform and handling of knowledge and information exchanges. Roy et al. (2004) investigated supplier-customer collaborations for innovation, highlighted the criticality of managing actor engagement in the relationships, without which the co-creation is unlikely to be understood thoroughly. There is little research on the processes of engagement, especially about VC in SMEs customer co-creation. We believe that our approach, tapping experiences and practices, should go some way to addressing the issues raised in the literature.

\subsection{Engagement and the virtual enabling of innovation}

Developing new products with consumers results in better tailored new products (Hippel, 1978), reduced lead time to market and lower costs in the innovation process (Von Hippel, 1986; Robertson, 1967; Ray and Ray, 2011). Product innovation is market-driven (Badawy, 2011), but partnerships allow firms to share R\&D costs and reduces perceived risks and uncertainties (Turnbull and Leung, 1986; Haeussler et al., 2012; Danneels, 2002). This is particularly important for SMEs lacking resources (Anderson and Ullah, 2014). In co-creation, actors interact and engage in a process of problem recognition, information search and collection, innovative ideas and commercialization (Rogers, 2003) which contribute to value creation (Hollebeek et al., 2016b). Firms thus benefit from engaging in creating and maintaining long-term relationships (Kumar and Pansari, 2016). Wiersema (2013) highlights the importance of strengthening the innovation-marketing interface, essential for synchronizing and commercializing product development in B2B marketing. Innovations resulted from supplier-customer partnerships tend to be incremental (Hauser et al., 2006, Biemans, 1991). Firms are more capable of producing incremental innovation, reflecting how such innovation builds on existing know-how, and with less uncertainty and risks (Von Hippel et al., 1999). Collaborative innovation has crossed geographical boundaries in recent years. In high-tech sectors like biorheology, firms benefit from information and resources flows, innovation opportunities and new markets through global networks, developed science knowledge based capacities and more international connections (Moodysson and Jonsson, 
2007, Gittelman, 2007, Segers, 2016) whereby the virtual plays an important role (Fontes, 2005, Muethel et al., 2012). Nonetheless, Hellstrom (2004) argues innovation is a process of social actions where the cognitive dimensions of innovation are embedded in social milieus and exchanges.

\subsection{Socialisation of customer engagement: co-creation of innovation}

Harmancioglu et al. (2007) argue that product innovation requires knowledge creation; a knowledge transfer and exchange process with new products as an outcome. Individuals thus play a critical role in the exchanges by engaging in network interactions (Numprasertchai and Igel, 2005). In supplier-customer collaborations, actors in supplier firms drive product specifics. They employ social skills to decode technical and organizational jargon into language that can be understood by the externals and vice versa (El Harbi et al, 2011; Tushman, 1977). Through ongoing joint knowledge-based activities and social exchanges, individuals engage with the customer's perspective (Anderson et al., 2007). Together they create new knowledge by integrating tacit knowledge exchanges leading to the development of new products (Trott, 2017; Dosi, 1993).

Our review thus indicates that engagement process has two key dimensions, the cognitive and the affective.

\subsubsection{Cognition and innovative engagement}

Cognition is the process of 'knowing' incorporating perception, reasoning, and judgment. It includes the knowledge, skills and strategies that a partner brings to the engagement (Madhavan and Grover, 1998; Roy et al., 2004) and is especially relevant for understanding information flow between actors (Dosi, 1988). Polanyi (1967) classically explained how knowledge type impacts on transferability.

1. Explicit knowledge resides in theories, documents, the Internet, reports, plans or textbooks. Such knowledge is transferrable in formal, systematic language and is relatively easy to articulate and communicate.

2. Tacit knowledge derives from personal opinions, judgements, experiences or guesswork. It is personal, informal and disorganized; it cannot be easily explained or transferred.

Collaborative innovation, as an engagement context, relies on sharing tacit knowledge (Howells et al., 2003). Corti and Lo Storto (2000) argue that familiarity with each other is necessary. It takes time to know each other sufficiently to 'engage' in acquiring know-how. Tacit knowledge is shared more easily between actors with common experiences (ibid.) and hence similar cognition processes. Finally, individual attributes shape behaviour in persuasion and decisions about adopting innovative ideas (Knight, 1967). Individual characteristics thus affect co-creation (Goswami and Mathew, 2005). Accordingly, these processes are inherently social. 
Moreover, Corti and Lo Storto (1997) found knowledge creation is influenced by ambiguity and uncertainty. Knowledge exchange becomes difficult when knowledge tacitness is high, created by ambiguity and lack of information caused by uncertainty. They recommended managing information flows by using a richer platform, face-face to exchange tacit knowledge when there is ambiguity (Nonaka and Takeuchi, 1994, Nonaka and Takeuchi, 1996) and for information flow to avoid uncertainty (Corti and Lo Storto, 1997). Corti and Lo Storto (2000) argue that neither tacit knowledge nor information flow can be managed, unless the expert is able and willing to illustrate it (Nonaka and Takeuchi, 1994, Nonaka, 1994). Actor engagement is thus embedded in complex social relationships (Athaide et al., 1996; Huang and Chang, 2008. Laud et al. (2015) identified this as the affective aspect of innovation and engagement (Roy et al., 2004).

\subsubsection{Affect and innovative engagement}

Where cognition is typically rational, affect is largely about emotions, although both play a complementary role in co-creation of innovation (McFarland and Ployhart, 2015). Affect refers to the relationships that influence engagement in new knowledge creation process (Polanyi, 1967). Close inter-personal relationships foster innovative ideas. Studies suggest that building strong ties with customers through social interaction is important for obtaining information and resources for mutual benefits in innovation (Dickson and Hadjimanolis, 1998; Pittaway et al., 2004; Morrissey and Pittaway, 2006).

Albrecht and Ropp (1984) studied affect in how individuals discuss innovative ideas in intraorganizational innovation and found product innovation a result of complex actor engagement with knowledge and information exchanges. New ideas arise from within social topics; for example, conversations solely about innovation are rare. Additionally, social activities help develop inter-personal knowledge and the close relationships which foster innovative ideas generation and development (Orr, 1990; Ruef, 2002). Freel and de Jong (2009) and Roy et al. (2004) argue that strong ties enable quality information flow and willingness to transfer tacit knowledge between trusted actors, enabling creative ideas. A network relationship with strong ties entailing a high level of trust is therefore extremely beneficial to complex and fine-grained tacit knowledge transfer ( $\mathrm{Mu}$ et al., 2008). This is because both actors see the knowledge source as being reliable and are willing to share a greater volume of knowledge (Anderson et al., 2007). This is particularly important for cocreation of new products (Koch, 2004).

Mu et al. (2008) found that the decision to trust and exchange knowledge depends on actors having knowledge of each other. Antcliff et al., (2007), Putnam (2000), Westerlund and Svahn, (2008) argue that bonding social capital inspires and fosters economic activities; homogenous sharing of attributes such as age, common social class, education and shared experiences facilitate trust building (Lincoln and Miller, 1979) and tacit knowledge exchanges (Dosi, 1988). We can thus see that developing affect complements cognition in product innovation. Given the value of a trusting relationship, face-face, the richest platform, seems best for building and developing the affect. 
We conclude from our review that supplier-customer engagement in B2B for co-creation of innovation is a relationship marketing process and is driven by social processes. Insights from the social networking literature suggest that bonding social capital is necessary to create the trust necessary for effective knowledge exchanges. Consequently, VC may enable some aspects of engagement but be less effective in others.

\section{Methodology}

Our research problem, the exploration of suppliers-customer VC engagement called for an interpretative approach, aiming to understand the social processes (Karatas-Ozkan et al., 2014). Our research was designed to tackle 'how' and 'why' questions through an informed examination of how the technology was employed. Our data was supplier's lived experiences of collaborative innovation, collected by interview (Hoang and Antoncic, 2003; Patton, 2002; Van Manen, 1990). In addition, an interpretative approach enabled discovery of our research concerns in context. Lee (1994) highlighted the importance of context in studying virtual platforms. The biotechnology sector in Scotland is known for excellence and a strong innovation culture (Henderson, 2015) where innovation networks are prominent and propelled by the pervasiveness of enabling technologies (Rampersad et al., 2010). The sector's 620 novel biotech organizations employ 37,400 people and turnover of $£ 3 \mathrm{bn}$, rank as the second largest in the UK and one of the largest and fast growing in Europe (Scottish-Gov., 2018). Most firms are small $(<50)$ or medium size with $<250$ employees and are productive in new product development (Scottish-Enterprise, 2018). Analysis was inductive and compared data with data and data with existing literature; the constant comparative method that enables connecting theory with practice (Brodie et al, 2008). It uses comparative iterations of data analysis to analyse categories and patterns (Jack et al, 2015). Our objective, to explain and understand how engagement worked, called for interpretation of our respondent's experiences (Goulding, 2005). This analysis enabled us to develop an explanatory account to theorise engagement for innovation.

\subsection{Sampling}

We employed purposive sampling because of its relevance for the research enquiry (Mason, 2002). Dundee and Aberdeen were chosen as they are at a heart of the region (Bio-Dundee, 2016) with bioscience entrepreneurs pursuing innovation through their global networks using virtual platforms (Helard-Scoland, 2006; Plum and Hassink, 2011; Simba and Ndlovu, 2014; Vittoria and Lubrano Lavadera, 2014; Krätke, 2014), which enabled them to be part of a global community for knowledge exchange and bringing about collaborative innovation (McCarthy et al., 2007). They fitted well with the study focus of this study. With support from Scottish Enterprise, all biotechnology product manufacturing and trade firms were identified from the industry index. The respondents were identified and selected by discussions with experts in the industry and by referencing secondary sources (Abrahamsen and Håkansson, 2015). The final sample of firms consisted of 12 biotech companies with 8 to 70 employees, all were 
involved in biotech-manufacturing or bio-pharmacy products manufacturing and trade (Hendry and Brown, 2006).

We interviewed one or two owners/managers from each firm who were boundary spanners (Johannisson, 1995) in firms engaged in joint product development with customers (Liamputtong and Ezzy, 2005). A total of 17 respondents are described in Table 1 (Appendix I), but names have been anonymised. All had been involved in more than 3 joint product innovations (Freeman and Engel, 2007) and worked in the firms for over 7 years and with general IT training. The sample theoretically possess the characteristics suitable for the research enquiry (Abrahamsen and Håkansson, 2015). We also referred to corporate websites, industrial reports and news, brochures and corporate meeting notes as desk research materials (Patton, 2002).

\subsection{Data collection}

In-depth interviews were unstructured but included questions about key topics derived from the research objectives in key areas co-creation of innovation, the use of VC and suppliercustomer engagement and relationships in the innovation process based on a phenomenological approach (Van Manen, 1990; Moustakas, 1994). We used the long interview technique (McCracken, 1988) where dialogues were largely set by respondents, but responded to the broad topics (Thompson et al., 1989). For example, we asked 'how did you first learn about this customer', relevant answers were followed up, so we learned about the respondent's lived experiences of engagement in collaborative relationships (Van Manen, 1990; Moustakas, 1994). The interviews (with one researcher) lasted an hour or two and were recorded and transcribed. Our interview guide is in Appendix II. After a preliminary analysis, we found some gaps in our data and re-interviewed six respondents in short telephone interviews (20 minutes) (Patton, 2002).

\subsection{Data analysis}

The data were an extensive mixture of anecdotes, stories, examples and fieldwork notes. An inductive approach identified emerging themes (Denzin and Lincoln, 1994; Lockett et al., 2012). We followed Moustakas (1994) suggestion of first becoming very familiar with the data, then discarding irrelevant material to focus on what appear the key events deemed important. In turn this early analysis guided further data collection. The analysis itself was informed by Smith et al. (2009) who propose making sense of the data by linking parts to the whole and by immersing in the respondents' lifeworld. We had transcribed the data and repeatedly read the transcripts. The preliminary analysis was descriptive, aiming to first describe 'what is going on here', and identify emerging themes on the engagement about relationship development and VC use in co-creation (Simmons et al., 2013). Going backwards and forwards between data and theories involved an iterative process of reviewing data with emerging categories (Corbin and Strauss, 2008). This constant comparison is described by O'Connor et al (2008: 41), "constant comparison assures that all data are systematically 
compared to all other data." Jack et al. (2015) explain how incidents, experiences and activities are first compared and contrasted into themes. Repeating patterns of emerging themes were sought across the transcribed scripts. We employed NVivo 10 to assist the analytical process, mainly for managing the extensive volume of data. The second round of analysis was concerned with explaining. Here we sorted the themes into an explanatory account of how and why demonstrated in the behaviours and phenomena. This involves connecting and relating patterns to explain how the engagement develop alongside how VC was used; thus, building and identifying plausible links, connections and causal relationships between themes and in the patterns throughout the data (Aarikka-Stenroos et al., 2014). Table 2 (Appendix III) intended to show examples in the findings, also plots our process.

\section{Research findings}

For an insight of a phenomenon, Smith et al. (2009) and Thompson et al., (1989) argued that we should try to make sense of the connections, this inductive process helps develop our understanding of the engagement process. Our research objective was to explore how well and in which ways VC worked in facilitating the engagement in collaborative innovation process. Accordingly, we first report on why the respondents used VC; then show what exchanges taken place as actors interacted to develop the relationships and where and how VC was used, and then discuss how the practices and purposes of engagement are enabled or limited by VC. We then develop our theoretical contribution from this analysis.

\subsection{VC use for engagement}

All our respondents viewed customer relationships as critical for their businesses, they were actively involved in interacting with customers for ongoing product development, as Bob explains, "It's constant development ... incremental innovation ... minor changes really" (I, A). The respondents employed VC when discussions were necessary, but when geography made this difficult:

"... lots of companies are far away, so we videoconference." (G, $\mathrm{Cl})$

"it was exciting, it doesn't waste time ... it sure beats travel" (D, Bt).

They were very open about how the technology was used. Andy provided a good example from joint product development with a client, "we held videoconferences several times weekly" (A, H). VC thus substituted for physical meetings. Respondents were passionate about engaging via $\mathrm{VC}$, crediting it as adding value to the relationships. The virtual platform was room-system as well as computer-mediated VC. All considered their experience very positively. Moreover, we were told about the content, reflecting our ladder of media richness; respondents ranked face-face as the richest, followed by VC and audioconferencing; as Darren put "I'd say face-face, then videoconference, then audioconference, then email" (D, $\mathrm{BT})$. Interestingly, there was some caution about the ease of use, Peter reported, "we don't 
want to keep phoning them (customers) up for conferences, don't want to annoy them, you get much more outcome in face-face, like interactiveness and richness" (P, Cy). Respondents were aware that overuse of VC risked spoiling the relationships.

In the following, we analyse the data by looking into how the collaborative relationships began, how the VC was used in the relationships building and development, led to successful joint new products development. This demonstrated a deepening engagement with particular relationship outcomes in a progress of developing progressive relationships. We note VC complements face to face, rather than replacing it.

\subsection{Exchanges in building supplier-customer relationships and VC engagement}

Collaborative relationships generally commenced from customers encounters about technical problems/needs and their primary contact as seeking for technical solutions. These interactions resulted in ideas generation. We conceive this as the first rung of the engagement ladder, initiating knowledge exchange and burgeoning trust. Nonetheless, before using VC actors exchanged personal information, triggering the connection and stepping into the engagement ladder.

"... we go for a lot of conferences ... exhibitions ... for a start, it's a dialogue ..." (M, CM)

"... I understand, this is me ... what I am doing ... what do you think ... we didn't talk about the business ... just make that contact ..." (S, A)

These early face-face meetings at conferences, exhibitions and bioscience trade shows were seen as initiating the relationships; actors talked to each other and generated information flows. The actors developed affect, whilst the social milieu helped:

"... (face-face) that will be the most lucrative social ... for a start." (M, CM)

"... prefer to meet somebody first ... to understand people ... look eye-to-eye with people, once I have met them, anything else works ..." (S, A)

Face-face exchanges with eye contacts, body gestures and immediate responses in the bioscience community was the most appropriate for creating intimacy and exchanges of personal knowledge in a social milieu. Moreover, these interactions included an element of cognition and instrumentality blended in those social exchanges:

"... (it was a chance of conversation) I was curious, 'why he picked up on that sort of redundant physics research'. They actually built an equipment technology and utilise it and had a purpose ... this is my interest, you did this, tell me more about it ... they had a problem ... because I can see potential applications of this ... we got into dialogues almost straight away." (I, A)

We can see how the respondent and customers became engaged in exploring common interests and shared goals in work related issues, thus developing cognition. Such engagement also established their professional identities in the minds of each other. Faceface dialogues in the social milieu of industrial conferences enabled cognition as an 
understanding of each other to emerge and to build primary trust. We see this as progressing up the engagement ladder.

"... ... I knew what their problems were ... you tell people roughly what you are going ... you are honest with people ... that's the key really ... have a look at the organisation as well ...." (S, A)

In identifying common interests and mutual benefits shown above, the respondents highlighted the importance of building primary trust in individuals and organisations through developing the affect and the cognition, in particular the importance of the affect in determining the cognition. They valued these pre-engagements before VC, as Ed put:

"... so we find it (VC) very useful ... if you have already known the people ... you need to establish personal relationship first." (E, Bt)

"... I always want to talk to them.... to arrange a meeting face-face, it's always the most important thing ... That's the trigger for the relationship." $(\mathrm{F}, \mathrm{Cm})$

Knowing people and acquiring knowledge about them, served as the base for bridging social capital about common interest and identity and forming primary trust, establishing the foundational rung for ensuring VC interactions. Additionally, series of exchanges via email and phone calls backwards and forwards, along with website visits were employed, as Bob explained:

".. they visited our website ... had looked at the tests we did and the products ... we were contacted by them." $(\mathrm{B}, \mathrm{CL})$

"... that was a telephone conversation. (for their problem) We said, 'this is what is going to happen ... how it is going to break down ... what is going to come out it' ... in an email" $(\mathrm{I}, \mathrm{A})$

Conceptually, these interactions stabilised the ladder, allowing further progress. These preengagements through leaner platforms gave access to objective data and helped the supplier's understanding of customer problems, getting to know the partners' organisations and the respondents' preliminary ideas on the technical solutions prior to VC. This enabled partners to establish a pre-understanding of the technical issues, reduce uncertainty and provided time to think about the next step, preparing.

"... before the videoconference, you have to prepare." (I, A)

Moreover,

"We generally send the presentation by email or post in advance, so they can look at it at the same time we present it (in VC)" (B, Ci)

Interestingly, using VC could also be time and resource consuming, (lasting for "an hour or 23 hours" $(\mathrm{M}, \mathrm{C})$ involving owners/managers and scientists with different functional roles.

Following on from these antecedents, respondents used VC as follow-ups for technical discussion, especially when face-face was less practical due to geographical distances. For 
example, Keith described VC use for understanding technical problems and propositions about solutions for customer's problems from which new product ideas were initialized.

"... meeting technical experts to understand the problem, the technical details" ( $\mathrm{K}, \mathrm{Cr})$

VC enabled synchronized and content tailoring, conveying non-verbal cues was important for respondents. Steve described how the facilities in VC allowed narratives and explanations to emerge.

"... we can write up (on a board) what we are doing, and it comes up on the screen down there as well. So, we can work as if we are working on the same board but in two quite different places ..." $(S, A l)$

George pointed out the benefits of the immediacy and interactiveness of VC,

"... for brainstorming and for the understanding of the problem ... because it is questions and answers, interactive" (G, Cl)

We can see that VC was used when knowledge exchanged was equivocal or not defined; for example, in brainstorming. Demonstrations aided explanation in real time and were helped by speedy responses through verbal and non-verbal cues, which could not be achieved by a lean platform. Importance and utility were placed on being able to immediately respond and clarify. Thus, it appears that VC really helped tacit knowledge exchanges (technical knowhow) in terms of understanding each other and seeking technical propositions for solutions. Importantly, it seems that immediate responses, as well as clarity are key conditions.

Whilst the above is about developing and strengthening existing links, we were also told about how it also offered a stall for setting out what was on offer. Conceptually, we see this as envisaging the next rung of the ladder.

"Conversations (in VC) can include the purpose of contact, show the interest for scientific presentation and business discussion." (J, Cy)

VC engagement was purposeful. As the actors developed collaboration from those interactions, tacit knowledge exchanges through VC were reported as helping to identify common interests and mutual benefits (bridging social capital). An outcome of the exchanges was making connections, "... once you understand what you both want ... we got together, because we both recognised this mutual benefit here." (J, Al) They became engaged in closer exchanges, to develop committed partnering relationships and moving further up the engagement ladder.

\subsection{Closer exchanges in developing supplier-customer relationships and VC engagement}

Relationships progressed as the actors co-developed the technical proposals. As Chris commented, "there will be some changes made, we consistently update, progress or ask them for different bits and pieces ... we do it with raw data, analysed and interpreted ..." (C, R), as a result of developing identified common interests, the partners formalised contracts for new product development, "... then we wrote a proposal and emailed it, went backwards and 
forwards, over about 3 months ... we got the agreement we were happy with ... and signed." $(J, C y)$ Joint product development went forward following the legal contract. They went into deeper committed relationships, bonded to work towards the same goal, the new product as the solution, sharing risk and mutual benefits; thus moving towards the top of the engagement ladder.

Although we conceptualise the process as moving up the latter, there is a horizontal component which is about consolidating the position on the ladder. For example, there were joint activities following new products sales. Respondents offered technical advice on and training for using new products via VC, as Chris commented,

"... videoconferencing ... I was in a seminar delivering the training of using the new product last week, a chap from ... (US) speaking ... came on the screen ... we talked, and everyone talked to everyone ... that was perfect." $(C, R)$

As such, they made deeper connections through engaging in the applications of new product, creating bridging social capital (Eklinder-Frick et al., 2011) in the committed relationships. Both partners were bioscience professionals who understood each other's technical languages and had similar industrial knowledge and backgrounds,

"... the relationships have been built ... so they were feeling very confident if they talked to us who knew what they were talking about ... our customers are biotech researchers in a particular field." (J, C)

This sharing, namely bonding social capital enabled tacit knowledge exchanges via VC. The respondents and customers worked towards a long-term relationship maintenance after the new product sales, "the relationship was not finished once the collaboration project was finished, we knew each other." (A, K). Accordingly, from a practice perspective VC engagement saved travel time, but enabled supplier's technical supervision. The process was very effective after they had had built more interpersonal and organisational knowledge about each other. Seen this way, the ladder concept helps us to understand how relative position on the ladder relates to the effectiveness of interactions. The higher the relationship, the easier and more effective the interaction with significant know-how and information exchanged on new technical product development.

Bonding via previous face-face meetings facilitated the respondents' engagement in VC. Following the new products sales, VC served as the means to continue and develop the cognition in between face-face meetings or the exchanges via other lean platforms in maintaining long-term relationships,

"... usually we keep in touch with that person from time to time and have chats ... I know the personal very well, almost like a friend ... to keep the relationship ... it's a dialogue and then VC." $(A, K)$

VC engagement enabled the actors to remain connected between meetings, as Peter showed "a few weeks ago, he gave us a talk through VC, to another side of the pharmaceutical companies". Moreover, VC complemented face-face meetings; 
"... but we backup all these (via video conference) with visits with customers mostly ... we tend to have quarterly or twice annual meetings ... to sit face-face and look at their problems or programmes ... gave (technical) recommendations." (S, Al)

VC engagement was an easy solution, but complementary to face-face. Face-face was recognised as a main platform substantial for maintaining close relationships, contributed to the cognition due to the highest richness in enabling tacit knowledge exchanges. Bill commented,

"... (VC) works better if you know the people, as you know their reactions and what it means." $(B, C y)$

We can see that VC engagement became positive with bonding established as a facilitating condition for the cognition. In the relationship process, the reiterative VC engagement served as a source of obtaining ongoing inter-personal knowledge and for maintaining social capital. Exchanged inter-personal knowledge became bonding social capital for developing trust in the committed relationships. Bill summed it up, "... for trust development, video-conferencing would be better (than email), because you can see someone ... you knew their expertise ... For an ongoing relationship, it's more about trust, you know ... and again it (VC) is interactive a bit more ... ultimately, to make effort you still need to meet someone face-to-face." (B, Cy).

\subsection{Critical exchanges in supplier-customer engagement}

Throughout the collaboration partnerships, we noted that the respondents valued certain critical exchanges for developing affect. Sometimes however, VC was perceived as inappropriate for such an engagement,

"the same as you did for building up the relationships at the beginning, if I knew something about them, e.g. just have a baby or ... I do include some social chat, but I wouldn't include that in a videoconference..." $(G, C)$

"I think it is a half-way house, it's still a bit artificial there" (C, Re)

Being an electronic platform, VC has its limitations in conveying social presences and for engaging in strong affect. Moreover, we also found some critical exchanges for decision making were limited in VC.

"decisions don't get made just right away, where you are looking at the relationship, money involved ... not based on a videoconference." $(C, I)$

"... legally we know what we want to do and what they want to do, it has to be faceface." (J, C)

We can see that VC has limitations when knowledge tacitness was at a high level, characterised by multi-disciplinary topics (Kogut et al., 1992). Appropriateness and richness in critical decision making was stressed, 
"... when you try to be involved in serious negotiations, it's always important to see how the other person reacts to something (it needs face-to-face)." (B, Cy)

In addition, it appears that nuances and flexibility are better in face-to-face,

"... and you can change your approach accordingly, that's not easy to do (by VC)" (B, Cy)

Furthermore, when the engagement involves an important customer relationship or deal, '... for an important customer or business deal, we tended to meet face-face instead of having video-conferencing ...' $(A, H)$, being virtual VC was insufficient to meet the required richness of interactions as determined by the value of a partnership. Critical exchanges seem best completed at a richer platform, face-face for successful collaborations.

\section{Discussion}

In this section, we identify and discuss a theoretical model of engagement via VC. Our objective was to understand the ways by which the supplier-customer engagement is furthered or hindered by VC. We examined engagement in the context of the suppliercustomer relationship process in co-creation of incremental product innovation in SMEs, arguing that this context could highlight B2B engagement practices.

Overall, our findings confirm Mei-Ying and Yung-Chih (2014) and Caballer et al. (2005)'s point that the VC platform enables communication efficiency in actor interactions. By locating VC in the engagement process in co-creation of innovation, we found it employed as an alternative when geographical distance or time was a barrier to face-face meetings. In practice it complemented the process by offering the richest virtual platform (Daft and Legel, 1986) for developing mutual cognition. Moreover, VC was used to reinforce the affect dimension, albeit as supplementary in renewing connections. Whilst this explains why VC appealed, this study contributes to the literature by revealing how engagement evolved.

Investigating from a supplier perspective, we found engagement to be processual in a longterm relationship. The process was characterised by interactions that grew from increasing affect and cognition. The interactions both produced and employed affect and cognition as social and instrumental means and ends. We conceptualise this process as a ladder of engagement. The ladder concept captures 'stages' as a process towards full engagement. It illustrates how each stage or rung provides the means of progressing to the next rung of engagement with the nature and content of engagement as it develops over time.

Using the conceptual leverage of networking as a process for exploring engagement in cognitive and affect dimensions, we saw how bonding and bridging social capital (Edwards, 2002; Lincoln and Miller, 1979; Schuller et al., 2000; Putnam, 2000) were used to develop affect and cognition to enable tacit knowledge exchange (Polanyi, 1967). In turn, the growth of inter-personal knowledge in both dimensions became an enabling condition that allowed the sharing of tacit knowledge. 
In essence, to progress the relationships there were stages and criticality of engagement. Borrowing from the marketing and entrepreneurial literature, we propose a conceptual 'ladder of engagement', shown in Figure 2 which highlights the engagement via VC. The ladder concept has been usefully employed for customer loyalty (Boden, 2009). However, recently Zwan et al. (2010) argued the ladder concept can show entrepreneurial stages, thus offering an ordered and sequential progression of degrees of involvement to develop committed and further long-term relationships. The notion allows us to see and distinguish different activities and practices and to understand how engagement develops.

The first rung on the ladder of engagement is 'participation and involvement', a gap in the literature (Brodie et al. 2013). It describes engagement at an early stage of relationships where actors exchange in order to begin to know each other through affect and become involved in exchanging tacit knowledge to identify common interests. It is used to understand the technical needs or problems and look for solutions. At this stage engagement may lead to propositions about technical solution and identification of common interests and shared goals in commencing the B2B relationships.

In this process, actors participate in and began developing affect, a key characteristic of building business networks via social networking, especially for smaller businesses, differing from large organisations by branding effects or reputation (Erevelles et al., 2008). VC appeared to be inappropriate for initiating a new relationship. We believe this can be explained by the limited media richness of VC, inappropriate (Daft and Legel, 1986) to convey social presences (Dennis and Valacich, 1999), for socialising. We saw how primary trust was initiated and mainly built on affect in social milieu. Within this process, bonding social capital is formed based upon sharing individual knowledge and identity and enabled by willingness to collaborate and reliability.

Cognition, along with the established affect, is facilitated and better enabled by face-face meetings. These are a richer platform for eye contact, body gestures and immediate responses to build primary trust in both dimensions in early stage relationships. As indicated by Turnbull and Leung (1986) and Haeussler et al., (2012), uncertainty and perceived risk are high at the beginning of collaborative innovation, the primary trust is important for reducing risk and uncertainty, and therefore the costs, in particular for SMEs lacking resources (Anderson and Ullah, 2014). Once primary trust is in place, the VC engagement worked in a latter phase 'involvement', for tacit knowledge exchanges and identifying common interests and shared goals, the cognition between the respondents and their customers.

The second rung, 'commitment' is characterised by deeper, closer exchanges as collaboration relationships develop to the contractual and post-contractual phases. Bonding social capital is represented by shared industrial knowledge and the familiarity between individuals as well as in firms and a shared goal on technical problem solving. Bridging social capital linked common interests and mutual benefits, consolidating the previous engagement and enabled the partners to work towards committed partnerships.

VC engagement enabled complex technical advice and training as knowledge sharing. But the more complex tacit knowledge exchanges and integration of that knowledge developed 
through cognition, knowing each other and in closer connections. Furthermore, VC exchanges acted as a continuing connection between face-face meetings, refreshing shared interests and fostering a bonded long-term relationship. VC maintains the links. It renews social capital by the complementary connecting of VC. Moreover, exchanges via other lean platforms (Daft, 1986; Daft, 1984) play a role of creating what Albrecht and Ropp (1984) identified as information flows and tacit knowledge exchanges. These two rungs of engagement represent increasing trust and closeness, creating fertile conditions for tacit knowledge exchange in deeper connections.

Figure 2. Videoconferencing engagement in supplier-customer relationships in cocreation of innovation: A dyadic perspective

\section{Primary trust}

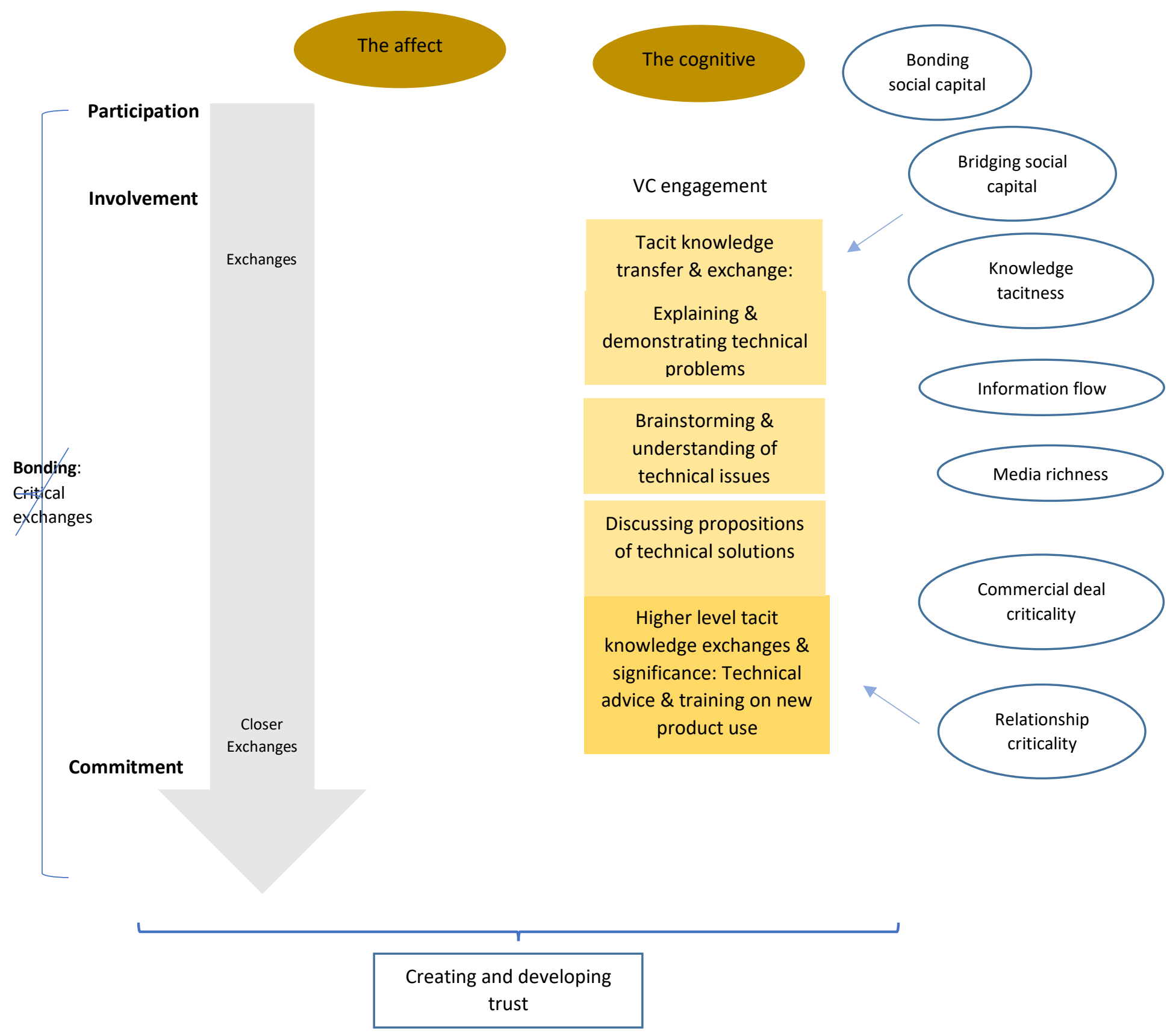

\section{The affect}


The third rung, 'bonding' is represented in those critical exchanges within the relationship process which determine the progress of successfully committed and long-term relationships. On this rung, collaboration for developing new products required critical exchanges with strong affect and a high level of tacitness in tacit knowledge exchanges (Insch et al., 2008). $V C$ is insufficient to enable those critical exchanges. In addition, our examination shows that VC is not the preferred option for critical deals or key customers of critical relationships (Wiersema, 2013; Davies et al., 2010, Ivens et al., 2009) to the SMEs. VC was a lean platform; only face-face developed sufficient strong affect to enable the cognition.

Finally, we note that the process of engagement was complex and dynamic. It was founded on human interactions that created and shared social capital by developing affect and mutual cognition. The elements of critical, but tacit knowledge flows and relationship building relied upon the media richness of VC to supplement and complement physical meetings.

\section{Theoretical Implications}

The contribution of this study lies in our explanations of engagement practices and the employment of virtual technology. First, we extend the engagement literature by exploring engagement in the $\mathrm{B} 2 \mathrm{~B}$ relationships in the context of co-creation of innovation, a gap in the B2B literature in terms of Marketing and Innovation interface (Wiersema, 2013). Specifically, we offer an understanding of supplier-customer interaction and value co-creative experiences (Brodie et al., 2011).

We found that engagement in dyadic interactions is a dynamic and evolving process of human rather than economic interactions (Morgan and Hunt, 1994), of sharing and creating social capital. Drawing on the concepts of social capital, we added a new stream in the epistemologies of engagement and offered the concept of an engagement ladder to model those interactions. We showed how this differs from that in B2C engagement applied as brand management (Vernette \& Hamdi-Kidar, 2013; Vivek et al., 2012). Engagement in B2B markets in new product development involves a committed and long-term relationship with trust developed through networking (Anderson and Hardwick, 2017; Larson, 1992). For cocreation, engagement is processual and socially enacted. However, it leads to the economic outcome of NPD through partners combining complementary resources and sharing risk and uncertainties (Turnbull and Leung, 1986, Haeussler et al., 2012).

We identified affect and cognition serving as two key intertwined aspects in the B2B relationships. These foster close connections with customers in a long-term relationship (Wiersema, 2013). We filled some gaps in the literature by showing the process of engagement evolved from an affect dimension where social networking built primary trust (Miller et al., 2007). We explained how engagement is founded on trust and close social relations. Within this, sharing bonding social capital played an enabling role in initializing what Brodie et al. (2013) described as participation and involvement. Cognition, knowing and understanding the other underpins engagement by forming bridging social capital (Anderson et al., 2007). The social process encapsulates and nurtures this cognition of common interests and shared goals. Moreover, we found that bonding social capital in terms of sharing homogeneous individual identifies and characteristics and increased inter-personal 
knowledge in social and personal aspects served as a glue (Anderson and Jack, 2002) to enable, initiate and sustain engagement. Therefore, engagement is embedded in, endowed with shared bonding social capital and yet presents an outcome of interactive bridging social capital processes (Laud \& Karpen, 2017). The processes evidence what Brodie et al. (2011) proposed engagement as a series of aggregated states with increased closeness in affect and increased levels of knowledge tacitness and significance of cognition as actors interact over time in arriving at a committed collaborative relationship.

Secondly, drawing on the owners/managers experiences of the engagement process in collaborative innovation, we explain how different elements shape the engagement process entailing the dynamic process of bonding and bridging social capitals, leading to the outcome of co-creation of NPD in dyadic relationships. We believe that this finding explains the richness of engagement situations in B2B in the SMEs context (Wisersema, 2013).

Contributing to the B2B literature we demonstrated how virtual technology was limited in its capacity for enabling engagement in B2B. Although VC appears to be a more economic platform than face-face it is insufficient for initialising affect in a new relationship and in 'bonding' whereby critical exchanges take place. These can be explained by recognising that engagement is a dynamic social capital process of human interactions.

Our qualitative approach to this new phenomenon, or rather newly recognised phenomenon of engagement in B2B, allowed our insights into processes and the dynamics of interaction (Hakanen, 2014; Denzin and Lincoln, 1994). Our phenomenological approach was critical for obtaining an understanding of the lived experiences by making sense from those experiences and linking parts to the whole (Moustakas, 1994; Patton, 2002).

\section{Practical Implications}

Managing supplier-customer engagement in co-creation of innovation using VC can be complex and raises challenges to owners/managers who are also scientists (Ahn and Meeks, 2008). Here our phenomenological approach may be particularly useful because we build from the actual experience of the respondents. Our more abstract theory should thus carry practical significance for explaining and understanding how engagement works in practice.

We recommend owners/managers note how the social investment of time and effort leads to mutual cognition. In turn this builds the social capital and trust which may be necessary for knowledge sharing ad commitment. Although this may seem an indirect approach for marketing to customers, we argue it is essential for marketing with customers. We also suggest that owners/managers should be aware that building on primary trust requires further social investment to increase inter-personal knowledge and the shared cognition that foster close engagement.

$V C$ is a useful tool in the engagement process but it has limitations especially for the affect and cognition dimensions. However, its strength lies in convenience for supplementing and maintaining the 'closeness' required in engagement. VC offers unprecedented reach. However, it is not sufficient rich for critical exchanges. Engagement via VC is well suited to 
technical exchanges. However not effective for close exchanges building personal relationships or complex technical exchanges. Whilst it works well for maintaining closeness, it is poor for developing intimacy at the beginning of relationships. However, VC can be a useful supplement for closer engagement and maintaining a fruitful long-term relationship.

The findings add some novel insight into our understanding of the choice and applications of interactive platforms for supplier-customer engagement. The topic which has been largely neglected as a research area in B2B marketing. Specifically, the findings show how VC facilitates the cognitive dimension of actor engagement and supports the affect dimension.

\section{Limitations and Future Research Directions}

This study has several limitations. The results are based on user experiences of VC which are very subjective (Dennis and Kinney, 1998). They were collected only from the supplier perspective, one side of engagement partners. The sample size is small and focuses on one sector in a single country; future research could extend to other contexts, sectors and countries. Our findings may not be generalisable to a large population, but may, we hope, generalize at a conceptual level (Jack et al., 2004). Nonetheless as markets become more global, VC will play an important role in engagement. The schema drawn from this study serves as a base for further research into this area. Future studies may seek to collect data from the other side of business partners in the co-creation for innovation, to focus on customers looking into customer experiences in B2B engagement. More research is to be done with bigger sample sizes and in exploring engagement relationships of SMEs in other industries and of different countries. We hope that the explanatory themes developed in this study will further research in the engagement more generally.

\section{Notes}

Bonding social capital refers to the connections between individuals (like-minded people) that share homogenous attributes such as age, education, common social class and shared experiences that facilitate trust building (Antcliff et al., 2007; Edwards, 2002; Lincoln and Miller, 1979; Putnam, 2000; Schuller et al., 2000; Westerlund and Svahn, 2008) in the engagement relationships.

Bridging social capital refers to building or developing the connections between individuals carrying out heterogenous elements (Edwards, 2002; Lincoln and Miller, 1979; Schuller et al., 2000; Putnam, 2000) such as heterogenous interests, collaboration objectives and interests in the engagement of the business partnerships. In the context of SMEs, the organizational interests or objectives intertwine with those of entrepreneurs' individuals. The organizational interests or objectives are mostly formed through their engagement in networking (EklinderFrick, et al., 2011; Miller et al., 2007). 


\section{References}

Aarikka-Stenroos, L., Sandberg, B. \& Lehtimäki, T. (2014). Networks for the commercialization of innovations: A review of how divergent network actors contribute. Industrial Marketing Management, 43(3), 365-381.

Abrahamsen, M. H. \& Håkansson, H. (2015). Caught in the middle: Buying from markets and selling to networks. Industrial Marketing Management, 49(4), 4-14.

Agrawal, A. K. \& Rahman, Z. (2015). Roles and Resource Contributions of Customers in Value Co-creation. International Strategic Management Review, 3 (1-2), 144-160.

Albrecht, T. L. \& Ropp, V. A. (1984). Communicating about Innovation in Networks of Three U.S. Organizations. The Journal of Communication, 34 (3), 78-91.

Anderson, A. R. \& Hardwick, J. (2017). Collaborating for Innovation: the socialised management of knowledge. International Entrepreneurship and Management Journal, 13(4), 1181-1197.

Anderson, A.R., Wallace, C. and Townsend, L. (2016). Great expectations or small country living? Enabling small rural creative businesses with ICT. Sociologia Ruralis, 56(3), 450-468.

Anderson, A. \& Li, J. (2014). Entrepreneurship and networked collaboration: synergetic innovation, knowledge and uncertainty. Journal of General Management, 40(1), 7-21.

Anderson, A. R. and Ullah, F. (2014). The condition of smallness: How what it means to be small deters firms from getting bigger. Management Decision, 52(2), 326-349.

Anderson, A. R., Park, J. \& Jack, S. L. (2007). Entrepreneurial Social Capital: Conceptualizing Social Capital in New High-tech Firms. International Small Business Journal, 25 (3), 245-272.

Anderson, A. R. \& Jack, S. L. (2015). An introduction to the constant comparative technique. In: Neergaard, H. \& Leitch, C. (eds.) Handbook of Qualitative Research Techniques and Analysis in Entrepreneurship. Cheltenham Glos: Edward Elgar Publishing, 15-20.

Anderson, A. R. \& Jack, S. L. (2002). The articulation of social capital in entrepreneurial networks: a glue or a lubricant? Entrepreneurship \& Regional Development, 14 (3), 193-2

Antcliff, V., Saundry, R. \& Stuart, M. (2007). Networks and social capital in the UK television industry: The weakness of weak ties. Human Relations, 60 (2), 371-393.

Ashley, C. Noble, S. M., Donthu N., \& Lemon, K.N. (2011). Why customers won't relate: Obstacles to relationship marketing engagement. Journal of Business Research, 64(7), 749756.

Athaide, G. A., Meyers, P. W. \& Wilemon, D. L. (1996). Seller--Buyer Interactions During the Commercialization of Technological Process Innovations. Journal of Product Innovation Management, 13 (5), 406-421. 
Badawy, M. K. (2011). "Is open innovation a field of study or a communication barrier to theory development?": A perspective. Technovation, 31 (1), 65-67.

Biemans, W. G. 1991. User and third-party involvement in developing medical equipment innovations. Technovation, 11 (3), 163-182.

Bio-Dundee. (2016). Bio-Dundee: Property [Online]. Available:

http://www.biodundee.co.uk/Property/ [Accessed 3rd May 2016].

Bowden, J.L.H. (2009). The process of customer engagement: A conceptual framework. Journal of Marketing Theory and Practice, 17(1), 63-74.

Brodie, R.J., Coviello, N.E. and Winklhofer, H. (2008). Contemporary Marketing Practices research program: a review of the first decade. Journal of Business \& Industrial Marketing, 23(2), 84-94.

Brodie, R. J., Ilic, A., Juric, B. \& Hollebeek, L. (2013). Consumer engagement in a virtual brand community: An exploratory analysis. Journal of Business Research, 66 (1), 105-114.

Brodie, R. J., Hollebeek, L. D., Juric, B. \& Ilic, A. (2011). Customer Engagement: Conceptual Domain, Fundamental Propositions, and Implications for Research. Journal of Service Research, 14, 3. 252-271.

Caballer, A., Gracia, F. \& Peiro, J. M. (2005). Affective responses to work process and outcomes in virtual teams: Effects of communication media and time pressure. Journal of Managerial Psychology, 20 (3/4), 245-260.

Carr, J., Gannon-Leary, P., Allen, B., Beattie-Huggan, P., Mcmurray, A. \& Smith, N. (2008). Eyes, ears and technology: An evaluation of the use of video-conferencing in BPR workshops. Business Process Management Journal, 14 (4), 569-587.

Conduit, J. and Chen, T. (2017). Transcending and bridging co-creation and engagement: conceptual and empirical insights. Journal of Service Theory and Practice, 27(4), 714-720.

Corbin, J., \& Strauss, A. (2008). Basics of qualitative research: Techniques and procedures for developing grounded theory (3rd ed.). Thousand Oaks, CA: Sage.

Corti, E. \& Lo Storto, C. (1997). Technical Problem-solving and Learning Process during Product Innovation: Some Empirical Evidence for the Development of a Theoretical Framework of Knowledge Creation in Small Firms. Proceedings of the PICMET' 97, Portland. Oregon, p.27-31.

Corti, E. \& Lo Storto, C. (2000). Knowledge Creation in Small Manufacturing Firms During Product Innovation: An Empirical Analysis of Cause-effect Relationships Among its Determinants. Enterprise \& Innovation Management Studies, 1 (3), 245-263.

Daft, R. L. \& Lengel, R. H. (1986). Organizational information requirements, media richness and structural design. Management Science, 32 (5), 554-571. 
Daft, R. L. \& Lengel, R. H. (1984). Information Richness. A New Approach to Managerial Behavior and Organization Design. In: STAW, B. M. \& CUMMINGS, L. L. ed. Research in Organizational Behaviour. Greenwich: JAI Press. 191-233.

Danneels, E. (2002). THE DYNAMICS OF PRODUCT INNOVATION AND FIRM COMPETENCES. Strategic Management Journal, 23, 12. 1095-1121.

Davies, I. A., Ryals, L. J. \& Holt, S. 2010. Relationship management: A sales role, or a state of mind?: An investigation of functions and attitudes across a business-to-business sales force. Industrial Marketing Management, 39, 7. 1049-1062.

Dennis, A. R. \& Kinney, S. T. (1998). Testing Media Richness Theory in the New Media: The Effects of Cues, Feedback, and Task Equivocality. Information Systems Research, 9 (3), 256274.

Dennis, A. R. \& Valacich, J. S. (1999). Rethinking media richness: towards a theory of media synchronicity. Systems Sciences, HICSS-32. Proceedings of the 32nd Annual Hawaii International Conference on System Sciences, 5-8 Jan. 1999. Maui, HI, USA, p.1017.

Denzin, N. \& Lincoln, Y. (1994). Handbook of Qualitative Research, ed. Thousand Oaks, CA, Sage.

Dickson, K. E. \& Hadjimanolis, A. (1998). Innovation and networking amongst small manufacturing firms in Cyprus. International Journal of Entrepreneurial Behaviour and Research, 4 (1), 5-17.

Dosi, G. (1988). Sources, Procedures, and Microeconomic Effects of Innovation. Journal of Economic Literature, 26 (3), 1120-1171.

Dosi, G. (1993). Technological paradigms and technological trajectories: A suggested interpretation of the determinants and directions of technical change. Research Policy, 22 (2), 102-103.

Easterby-Smith, M., Thorpe, R. and Lowe, A. (2008). Management research (ed.). London: SAGE.

Edwards, R. (2002). Social Capital, A Sloan Work and Family Encyclopaedia Entry, Chestnut Hill, MA, Boston College.

Eisenhardt, K.M. (1989). Better stories and better constructs: the case for rigour and comparative logic, Academy of Management Review, 16 (3), 620-627.

Eklinder-Frick, J., Eriksson, L.-T. \& Hallen, L. (2011). Bridging and bonding forms of social capital in a regional strategic network. Industrial Marketing Management, 40 (6), 994-1003.

El Harbi, S., Anderson, A.R. and Amamou, M. (2011). Knowledge sharing processes in Tunisian small ICT firms. Library Review, 60 (1), pp.24-36.

Erevelles, S., Stevenson, T. H., Srinivasan, S. \& Fukawa, N. (2008). An analysis of B2B ingredient co-branding relationships. Industrial Marketing Management, 37 (8), 940-952. 
Ferguson, R., Schattke, K. \& Paulin, M. (2016). The social context for value co-creations in an entrepreneurial network: influence of interpersonal attraction, relational norms and partner trustworthiness. International Journal of Entrepreneurial Behaviour \& Research, 22 (2), 199214.

Fleming, L. \& Waguespack, D. M. (2007). Brokerage, Boundary Spanning, and Leadership in Open Innovation Communities. Organization Science, 18 (2), 165-180.

Fontes, M. (2005). Distant networking: The knowledge acquisition strategies of 'out-cluster' biotechnology firms. European Planning Studies, 13 (6), 899-920.

Forrester Consulting (2008). How engaged are your customers? Available at: www.adobe.com/ngagement/pdfs/Forrester_TLP_How_Engaged_Are_Your_Customers.pdf [Accessed 15th May 2017].

Fram, S.M., (2013). The constant comparative analysis method outside of grounded theory. The Qualitative Report, 18 (1), 1-25.

Freel, M. \& De Jong, J. P. J. (2009). Market novelty, competence-seeking and innovation networking. Technovation, 29 (12), 873-884.

Freeman, J. \& Engel, J. S. (2007). Models of innovation: start-ups and mature corporations. California Management Review, 50 (1), 94-119.

Gaddefors, J. \& Anderson, A. R. (2009). Market creation: the epitome of entrepreneurial marketing practices. Journal of Research in Marketing and Entrepreneurship, 10 (1), 19-39.

Gambetti, R. and Graffigna, G. (2010). The concept of engagement. International Journal of Market Research, 52(6), 801-826.

Geertz, C. (1983). From the native's point of view: On the nature of anthropological knowledge. In C. Geertz (Ed.), Local knowledge: Further essays in interpretive anthropology New York, NY: Basic Books, 55-70.

Geldes, C., Heredia, J., Felzensztein, C. \& Mora, M. (2017). Proximity as determinant of business cooperation for technological and non-technological innovations: a study of an agribusiness cluster. Journal of Business \& Industrial Marketing, 32(1), 167-178.

Glaser, B. \& Strauss, A. L. (1967). The Discovery of Grounded Theory, New York, Aldine.

Gonzalez, G. R., Claro, D. P. \& Palmatier, R. W. (2014). Synergistic Effects of Relationship Managers' Social Networks on Sales Performance. Journal of Marketing, 78(1), 76-94.

Goswami, S. \& Mathew, M. (2005). Definition of innovation revisited: an empirical study on Indian information technology industry. International Journal of Innovation Management, 9 (3), 371-383.

Goulding, C. (2005). Grounded theory, ethnography and phenomenology: A comparative analysis of three qualitative strategies for marketing research. European journal of Marketing, 39(3/4), 294-308. 
Grönroos, C. \& Voima, P. (2013). Critical service logic: making sense of value creation and co-creation. Journal of the academy of marketing science, 41(2), 133-150.

Haeussler, C., Patzelt, H. \& Zahra, S. A. (2012). Strategic alliances and product development in high technology new firms: The moderating effect of technological capabilities. Journal of Business Venturing, 27 (2), 217-233.

Hakanen, T. (2014). Co-creating integrated solutions within business networks: The KAM team as knowledge integrator. Industrial Marketing Management, 43(7), 1195-1203.

Hardwick, J., Anderson, A., R. \& Cruickshank, D. (2013). Trust formation processes in innovative collaborations: Networking as knowledge building practices. European Journal of Innovation Management, 16 (1), 4-21.

Hardwick, J., Cruickshank, D. \& Anderson, R. A. (2012). Innovation in small business: comparing face-to-face with virtual networking. Journal of Business Strategy, 33 (5), 51-58.

Harmancioglu, N., Mcnally, R. C., Calantone, R. J. \& Durmusoglu, S. S. (2007). Your new product development (NPD) is only as good as your process: an exploratory analysis of new NPD process design and implementation. R\&D Management, 37 (5), 399-424.

Hauser, J.;Tellis, G. J. \& Griffin, A. 2006. Research on Innovation: A Review and Agenda for Marketing Science. Marketing Science, 25 (6), 687-717.

Hellstrom, T. (2004). Innovation as Social Action. Organization, 11 (5), 631-649.

Henderson, A. (2015). Investment in Life Sciences in Scotland: Challenges and Opportunities. Journal of Commercial Biotechnology, 21 (4), 29-34.

Hendry, C. \& Brown, J. (2006). Organizational Networking in UK Biotechnology Clusters. British Journal of Management, 17 (1), 55-73.

Hoang, H. \& Antoncic, B. 2003. Network-based research in entrepreneurship: A critical review. Journal of Business Venturing, 18 (2), 165-187.

Hollebeek, L.D., Conduit, J., Sweeney, J., Soutar, G., Karpen, I.O., Jarvis, W. and Chen, T. (2016a). Epilogue to the special issue and reflections on the future of engagement research. Journal of Marketing Management, 32(5-6), 586-594.

Hollebeek, L. D., Conduit, J. \& Brodie, R. J. (2016b). Strategic drivers, anticipated and unanticipated outcomes of customer engagement. Journal of Marketing Management, 32(5-6), 393-398.

Howells, J., James, A. \& Malik, K. (2003). The sourcing of technological knowledge: distributed innovation processes and dynamic change. R\&D Management, 33 (4), 395-409.

Insch, G. S., Mcintyre, N. \& Dawley, D. (2008). Tacit Knowledge: A Refinement and Empirical Test of the Academic Tacit Knowledge Scale. Journal of Psychology, 142 (6), 561-580. 
Ivens, B. S., Pardo, C., Salle, R. \& Cova, B. 2009. Relationship keyness: The underlying concept for different forms of key relationship management. Industrial Marketing Management, 38(5), 513-519.

Jack, S., Drakopoulou, D. S. \& Anderson, R. A. (2004). Social structures and entrepreneurial networks: the strength of strong ties. International Journal of Entrepreneurship \& Innovation, 5 (2), 107-120.

Jack, S.L., Anderson, A.R., Dodd, S.D. \& Moult, S. (2015). Using the constant comparative technique to consider network change and evolution. In Leitch, C. \& Neergaard, H. (Eds.), Handbook of Qualitative Research Techniques and Analysis in Entrepreneurship, p.21-51.

John, P. (2005). Opportunity recognition and product innovation in entrepreneurial hi-tech start-ups: a new perspective and supporting case study. Technovation, 25 (7), 739-752.

Johannisson, B. (1995). Paradigms and entrepreneurial networks - some methodological challenges. Entrepreneurship \& Regional Development. 7 (3), 215-231.

Jones, R., Suoranta, M. \& Rowley, J. 2013. Strategic network marketing in technology SMEs. Journal of Marketing Management, 29(5-6), 671-697.

Karatas-Ozkan, M., Anderson, A.R., Fayolle, A., Howells, J. and Condor, R. (2014).

Understanding entrepreneurship: challenging dominant perspectives and theorizing entrepreneurship through new postpositivist epistemologies. Journal of Small Business Management, 52 (4), 589-593.

Kawakami, T., Durmuşoğlu, S. S. \& Barczak, G. (2011). Factors Influencing Information Technology Usage for New Product Development: The Case of Japanese Companies. Journal of Product Innovation Management, 28 (6), 833-847.

Kleinaltenkamp, M., Plewa, C., Gudergan, S., Karpen, I.O. \& Chen, T. (2017). Usage centervalue cocreation in multi-actor usage processes. Journal of Service Theory and Practice, 27(4), 721-737.

Knight, K. (1967). A descriptive model of the intra-firm innovation process. The Journal of Business, 40 (4), 478-496.

Koch, C. (2004). Innovation networking between stability and political dynamics. Technovation, 24 (9), 729-739.

Kogut, B. \& Zander, U. (1992). Knowledge of the firm, combinative capabilities, and the replication of technology,. Organization Science, 3 (3), 383-397.

Komulainen, H., Mainela, T. \& Tahtinen, J. (2006). Social networks in the initiation of a hightech firm's internationalisation. International Journal of Entrepreneurship \& Innovation Management,6 (6), 3-3.

Kolter, P. \& Kellter, K. L. (2016). Marketing Management, Essex, Pearson Education Limited. 
Krätke, S. (2014). Global Pharmaceutical and Biotechnology Firms' Linkages in the World City Network. Urban Studies (Sage Publications, Ltd.), 51 (6), 1196-1213.

Kumar, V. \& Pansari, A. (2016). Competitive Advantage Through Engagement. Journal of Marketing Research, 53 (4), 497-514.

Larson, A. (1992). Network dyads in entrepreneurial settings: a study of the governance of exchange relations. Administrative Science Quarterly, 37 (1), 76-104.

Laud, G. \& Karpen, I. O. (2017). Value co-creation behaviour - role of embeddedness and outcome considerations. Journal of Service Theory and Practice, 27 (4), 778-807.

Laud, G., Karpen, I. O., Mulye, R. \& Rahman, K. (2015). The role of embeddedness for resource integration. Marketing Theory, 15 (4), 509-543.

Laroche, M., Kiani, I., Economakis, N. \& Richard, M. O. (2013). Effects of Multi-Channel Marketing on Consumers' Online Search Behavior: The Power of Multiple Points of connection. Journal of Advertising Research, 53 (4), 431-443.

Lee, A. S. (1994). Electronic Mail as a Medium for Rich Communication: An Empirical Investigation Using Hermeneutic Interpretation. MIS Quarterly, 18 (2), 143-157.

Lengel, R. H. \& Daft, R. L. (1988). The Selection of Communication Media as an Executive Skill. Academy of Management Executive, 2 (3), 225-232.

Lincoln, J. R. \& Miller, J. (1979). Work and Friendship Ties in Organizations: A Comparative Analysis of Relational Networks. Administrative Science Quarterly, 24 (2), 181-199.

Lockett, N., Jack, S. \& Larty, J. (2012). Motivations and challenges of network formation: Entrepreneur and intermediary perspectives. International Small Business Journal, 31 (8), 866-889.

Macdonald, E. K., Kleinaltenkamp, M. \& Wilson, H. N. (2016). How Business Customers Judge Solutions: Solution Quality and Value in Use. Journal of Marketing, 80 (3), 96-120.

Madhavan, R. \& Grover, R. (1998). From Embedded Knowledge to Embodied Knowledge: New Product Development as Knowledge Management. Journal of Marketing, 62 (4), 1-12.

Mason, J. (2002). Qualitative Researching, London, Sage Publications, Thousand Oaks

McCarthy, I. P., Pitt, L., Campbell, C., Van Der Merwe, R. \& Salehi-Sangeri, E. (2007). Exploiting the business opportunities in biotech connections: The power of social networks. Journal of Commercial Biotechnology, 13 (4), 245-257.

McCracken, G. (1988). The long interview, Newbury Park, CA: Sage Publications

McFarland, L.A. and Ployhart, R.E. (2015). Social media: A contextual framework to guide research and practice. Journal of Applied Psychology, 100(6), 1653-1677.

McKeever, E., Jack, S. \& Anderson, A. (2015). Embedded entrepreneurship in the creative reconstruction of place. Journal of Business Venturing, 30 (1), 50-65. 
Mei-Ying, W. \& Yung-Chih, W. (2014). The benefits of using unified communications systems for SMEs, International Journal of Electronic Business Management, 12 (4), 236-246.

Miller, N.J., Besser, T and Malshe, A. (2007). Strategic Networking among Small Businesses in Small US Communities, International Small Business Journal, 25(6), 631-665.

Morgan, R. M. \& Hunt, S. D. (1994). The Commitment-Trust Theory of Relationship Marketing. Journal of Marketing, 58 (3), 20-38.

Moustakas, C. (1994). Phenomenological Research Methods, Thousand Oaks, California, Sage.

Mu, J., Peng, G. \& Love, E. (2008). Interfirm networks, social capital, and knowledge flow. Journal of Knowledge Management, 12 (4), 86-100.

Muethel, M., Siebdrat, F. \& Hoegl, M. (2012). When do we really need interpersonal trust in globally dispersed new product development teams? R\&D Management, 42 (1), 31-46.

Muhlfelder, M., Klein, U., Simon, S. \& Luczak, H. (1999). Teams without trust? Investigations in the influence of video-mediated communication on the origin of trust among cooperating persons. Behaviour \& Information Technology, 18 (5), 349-360.

Nonaka, I. \& Takeuchi, H. (1994). The Knowledge-creating Company: How Japanese Companies Create the Dynamics of Innovation, New York, Oxford University Press.

Nonaka, I. \& Takeuchi, H. (1996). A theory of organizational knowledge creation. International Journal of Technology Management, 11 (7/8), 833-845.

Nonaka, I. (1994). A Dynamic Theory of Organizational Knowledge Creation. Organization Science, 5 (1), 14-38.

Numprasertchai, S. \& Igel, B. (2004). Managing knowledge in new product and service development: a new management approach for innovative research organisations. International Journal of Technology Management, 28 (7/8), 667-684.

Numprasertchai, S. \& Igel, B. (2005). Managing knowledge through collaboration: multiple case studies of managing research in university laboratories in Thailand. Technovation, 25 (10), 1173-1182.

O'Connor, M. K., Netting, F. E., \& Thomas, M. L. (2008). Grounded theory: Managing the challenge for those facing institutional review board oversight. Qualitative Inquiry, 14(1), 2845.

Oke, A. \& Idiagbon-Oke, M. (2010). Communication channels, innovation tasks and NPD project outcomes in innovation-driven horizontal networks. Journal of Operations Management, 28 (5), 442-453.

Orr, J. E. (1990). Sharing knowledge, celebrating identity: Community memory in a service culture. In: Middleton, D. \& Edwards, D. eds. Collective Remembering. London: Sage. p.169189. 
Ostrom, A. L., Bitner, M. J., Brown, S. W., Burkhard, K. A., Goul, M., Smith-Daniels, V. \& Rabinovich, E. (2010), Moving forward and making a difference: Research Priorities for the Science of Service, Journal of Service Research, 13(1), 4-36.

Panteli, N. \& Dawson, P. (2001). Video conferencing meetings: Changing patterns of business communication. New Technology, Work \& Employment, 16 (2), 88-89.

Patton, M. Q. (2002). Qualitative Research \& Evaluation Methods, 3rd ed. London, Sage Publications, Inc.

Phillips, B.J. and McQuarrie, E.F. (2010). Narrative and persuasion in fashion advertising, Journal of Consumer Research, 37(3), 368-392.

Pittaway, L., Robertson, M., Munir, K., Denyer, D. \& Neely, A. (2004). Networking and innovation: a systematic review of the evidence. International Journal of Management Reviews, 5/6 (3/4), 137-168.

Plum, O. \& Hassink, R. (2011). On the Nature and Geography of Innovation and Interactive Learning: A Case Study of the Biotechnology Industry in the Aachen Technology Region, Germany. European Planning Studies, 19 (7), 1141-1163.

Polanyi, M. (1967). The Tacit Dimension, New York, Doubleday.

Powell, W. W., White, D. R., Koput, K. W. \& Owen-Smith, J. 2005. Network Dynamics and Field Evolution: The Growth of Interorganizational Collaboration in the Life Sciences. American Journal of Sociology, 110 (4), 1132-1205.

Putnam, R. (2000). Bowling alone: the collapse and revival of American community, New York, Simon \& Schuster.

Rampersad, G., Quester, P. \& Troshani, I. 2010. Managing innovation networks: Exploratory evidence from ICT, biotechnology and nanotechnology networks. Industrial Marketing Management, 39 (5), 793-805.

Ray, S. \& Ray, P. K. (2011). Product innovation for the people's car in an emerging economy. Technovation, 31 (5-6), 216-227.

Rice, R., E. \& Case, D. (1983). Electronic Message Systems in the University: A Description of Use and Utility. The Journal of Communication, 33 (1), 131-152.

Robertson, T. S. (1967). Consumer Innovators: The Key to New Product Success. California Management Review, 10 (2), 23-30.

Rogers, E. M. (2003). Diffusion of Innovations, 5th Ed. New York, Free Press.

Rosetti, D. K. \& Surynt, T. J. (1985). Video Teleconferencing and Performance. Journal of Business Communication, 22 (4), 25-31. 
Roy, S., Sivakumar, K. \& Wilkinson, I. F. (2004). Innovation Generation in Supply Chain Relationships: A Conceptual Model and Research Propositions. Journal of the Academy of Marketing Science, 32 (1), 61-79.

Ruef, M. (2002). Strong ties, weak ties and islands: structural and cultural predictors of organizational innovation. Industrial \& Corporate Change, 11 (3), 427-449.

Ruokonen, M.' Nummela, N., Puumalainen, K. \& Saarenketo, S. (2006). Network management the key to the successful rapid internationalisation of the small software firm? International Journal of Entrepreneurship \& Innovation Management, 6 (6), 554-572.

Saldana, J. (2011). Fundamentals of qualitative research, ed. New York, Oxford University Press.

Sashi, C.M. (2012). Customer engagement, buyer-seller relationships, and social media, Management Decision, 50(2), 253-272.

Sawhney, M., Verona, G. \& Prandelli, E. (2005). Collaborating to create: The Internet as a platform for customer engagement in product innovation. Journal of interactive marketing, 19(4), 4-17.

Scottish-Enterprise (2018). Life sciences and biotech. Life Sciences Scotland [Online]. Available: http://www.scottish-enterprise.com/industry-support/life-sciences [Accessed 1st June 2018].

Schuller, T., Baron, S. \& Field, J. (2000). Social capital: a review and critic. In: Schuller, T., Baron, S. \& Field, J. eds. Social Capital. Oxford: Oxford University Press.

Scottish-Gov. (2018). Growth sector briefing - Life science. Available:

http://www.gov.scot/Topics/Statistics/Browse/Business/Publications/GrowthSectors Briefings [Accessed 22nd Feburary 2018].

Short, J., Williams, E. \& Christie, B. (1976). The Psychology of Telecommunication. London, John Wiley \& Sons, Inc.

Simmons, G., Palmer, M. \& Truong, Y. (2013). Inscribing value on business model innovations: Insights from industrial projects commercializing disruptive digital innovations. Industrial Marketing Management, 42, 5. 744-754.

Smith, J. A., Flowers, P. \& Larkin, M. (2009). Interpretative Phenomenological Analysis: Theory, Method and Research, ed. London, Sage Publications Ltd.

Storbacka, K., Brodie, R. J., Böhmann, T., Maglio, P. P. \& Nenonen, S. (2016). Actor engagement as a microfoundation for value co-creation. Journal of Business Research, 69 (8), 3008-3017.

Thomas, E. (2013). Supplier integration in new product development: Computer mediated communication, knowledge exchange and buyer performance. Industrial Marketing Management, 42(6), 890-899. 
Thompson, C., Locander, W., Pollio, H. (1989). Putting consumer experience back into consumer research: the philosophy and method of existential-phenomenology, Journal of Consumer Research, 16(2), 133-146.

Trott, P. (2017). Innovation management and new product development, 6th Harlow, Pearson Education Limited.

Turnbull, P. W. \& Leung, S. (1986). New Product Adoption by Pharmacists. Journal of Marketing Management, 2(1), 73-94.

Tushman, M. L. (1977). Special Boundary Roles in the Innovation Process. Administrative Science Quarterly, 22(4), 587-605.

Uzzi, B. \& Dunlap, S. (2005). How to Build Your Network. Harvard Business Review, 83 (12), 53-60.

Van De Vrande, V., Jong, J. P. J. D., Vanhaverbeke, W. \& Rochemont, M. D. (2009). Open innovation in SMEs: Trends, motives and management challenges. Technovation, 29 (6/7), 423-437.

Van Der Kleij, R., Schraagen, J. M., Werkhoven, P. \& De Dreu, C. K. W. (2009). How Conversations Change Over Time in Face-to-Face and Video-Mediated Communication. Small Group Research, 40 (4), 355-381.

Van Manen, M. (1990). Researching lived experience: Human science for an action sensitive pedagogy, New York, State University of New York Press.

Vermeulen, B., Vandermeulen, F. \& Demeester, P. (2005). An Open Generic Corba Programmable Videoconferencing Platform. Electronic Commerce Research, 5 (3/4), 383-399.

Vargo, S. L. \& Lusch, R. F. (2016). Institutions and Axioms: An Extension and Update of Service-Dominant Logic, Journal of the Academy of Marketing Science, 44(1), 5-23.

Vernette, E. \& Hamdi-Kidar, L. (2013). Co-creation with consumers: who has the competence and wants to cooperate. International Journal of Market Research, 55(4), 539561.

Vittoria, M. P. \& Lubrano Lavadera, G. (2014). Knowledge networks and dynamic capabilities as the new regional policy milieu. A social network analysis of the Campania biotechnology community in southern Italy. Entrepreneurship \& Regional Development, 26 (7-8), 594-618.

Vivek, S. D., Beatty, S. E. \& Morgan, R. M. (2012). Customer Engagement: Exploring Customer Relationships Beyond Purchase. Journal of Marketing Theory and Practice, 20 (2), 122-146.

Von Hippel, E.; Thomke, S. \& Sonnack, M. (1999). Creating Breakthroughs at 3M. Harvard Business Review, 77 (5), 47-57. 
Von Hippel, E. (1986). Lead users: a source of novel product concepts. Management Science, 32 (7), 791-805.

Von Hippel, E. (1978). Successful industrial products from customer ideas. Journal of Marketing, 42 (1), 39-49.

Walther, J. B. (1995). Relational Aspects of Computer-mediated Communication: Experimental Observations over Time. Organization Science, 6 (2), 186-203.

Walther, J. B., Anderson, J. F. \& Park, D. W. (1994). Interpersonal Effects in ComputerMediated Interaction: A Meta-Analysis of Social and Antisocial Communication. Communication Research, 21 (4), 460-487.

Weisband, S. \& Atwater, L. (1999). Evaluating self and others in electronic and face-to-face groups. Journal of Applied Psychology, 84 (4), 632-639.

Weisband, S. P., Schneider, S. K. \& Connolly, T. (1995). Computer-mediated communication and social information: status salience and status differences. Academy of Management Journal, 38 (4), 1124-1151.

Wendt, F. \& Harris, P. (1996). Intel's technology for videoconferencing. Management Decision, 34 (8), 34-40.

Westerlund, M. \& Svahn, S. (2008). A relationship value perspective of social capital in networks of software SMEs. Industrial Marketing Management, 37(5), 492-501.

Wiersema, F. (2013). The B2B Agenda: The current state of B2B marketing and a look ahead. Industrial Marketing Management, 42(4), 470-488.

Wolcott, H.F. (1990). Writing up qualitative research. Qualitative research methods, Thousand Oaks, CA: Sage.

Van der Zwan, P., Thurik, R. and Grilo, I. (2010). The entrepreneurial ladder and its determinants. Applied Economics, 42(17), 2183-2191. 


\section{Appendix I}

Table 1. Respondents' profile

\begin{tabular}{|c|c|c|c|}
\hline Respondent & Business & $\begin{array}{l}\text { Company } \\
\text { size (No. of } \\
\text { employees) }\end{array}$ & $\begin{array}{l}\text { Company } \\
\text { product } \\
\text { innovations }\end{array}$ \\
\hline $\begin{array}{l}\text { S.A. Business manager, }>15 \text { years in industry, age } \\
45-54, \text { UG }\end{array}$ & $\begin{array}{l}\text { Biotechnology product } \\
\text { and trade }\end{array}$ & 5 & $>4$ \\
\hline $\begin{array}{l}\text { J, A. Business manager, bioscientist, }>15 \text { years in } \\
\text { industry, age } 45-54, \text { UG }\end{array}$ & $\begin{array}{l}\text { Biotechnology product } \\
\text { and trade }\end{array}$ & 5 & $>4$ \\
\hline $\begin{array}{l}\text { D. B. Owner, business manager } \& \text { bioscientist, } \\
>25 \text { year in industry, } 45-54, P G\end{array}$ & $\begin{array}{l}\text { Biotechnology } \\
\text { manufacturing and } \\
\text { trade }\end{array}$ & 25 & $>240$ \\
\hline $\begin{array}{l}\text { H. B. Business manager \& bioscientist, >20 years } \\
\text { in industry; } 45-54, \text { UG }\end{array}$ & $\begin{array}{l}\text { Biotechnology } \\
\text { manufacturing and } \\
\text { trade }\end{array}$ & 25 & $>5$ \\
\hline $\begin{array}{l}\text { A.H. Owner, bioscientist, >15 years in industry, } \\
\text { 45-54, PhD }\end{array}$ & $\begin{array}{l}\text { Biopharmacy product } \\
\text { manufacturing and } \\
\text { trade }\end{array}$ & 20 & $>15$ \\
\hline $\begin{array}{l}\text { K.C, Owner, bioscientist, }>25 \text { years in industry, } \\
45-54, \mathrm{PhD}\end{array}$ & $\begin{array}{l}\text { Biotechnology product } \\
\text { and trade }\end{array}$ & 30 & $>7$ \\
\hline $\begin{array}{l}\text { G, C. Business manager } \& \text { bioscientist, }>20 \text { years } \\
\text { in industry, age } 45-54, \mathrm{PhD}\end{array}$ & $\begin{array}{l}\text { Biotechnology } \\
\text { manufacturing and } \\
\text { trade }\end{array}$ & 65 & $>90$ \\
\hline $\begin{array}{l}\text { B. C. Business manager } \& \text { bioscientist, }>20 \text { years } \\
\text { in industry, age over } 55, P G\end{array}$ & $\begin{array}{l}\text { Biotechnology } \\
\text { manufacturing, service } \\
\text { and trade }\end{array}$ & 65 & $>50$ \\
\hline $\begin{array}{l}\text { C. R. Business manager } \& \text { bioscientist, }>15 \text { years } \\
\text { in industry, age over } 45-54, P G\end{array}$ & $\begin{array}{l}\text { Biotechnology product } \\
\text { manufacturing, service } \\
\text { and trade }\end{array}$ & 8 & $>4$ \\
\hline $\begin{array}{l}\text { P. C. Owner, bioscientist, }>20 \text { years in industry, } \\
\text { age } 45-54, \text { PG }\end{array}$ & $\begin{array}{l}\text { Biotechnology product } \\
\text { manufacturing and } \\
\text { trade }\end{array}$ & 7 & $>50$ \\
\hline $\begin{array}{l}\text { C. H. Business manager, }>15 \text { year in industry, } 35- \\
44, \text { UG }\end{array}$ & $\begin{array}{l}\text { Biotechnology } \\
\text { manufacturing and } \\
\text { trade }\end{array}$ & 20 & $>4$ \\
\hline $\begin{array}{l}\text { A.K. Owner, bioscientist, }>10 \text { years in industry, } \\
\text { 35-44, PhD }\end{array}$ & $\begin{array}{l}\text { Biotechnology product } \\
\text { manufacturing and } \\
\text { trade }\end{array}$ & 3 & $>40$ \\
\hline
\end{tabular}




\begin{tabular}{|l|l|l|l|}
\hline $\begin{array}{l}\text { R.P. Owner, bioscientist, }>25 \text { years in industry, } \\
\text { over 55, PG }\end{array}$ & $\begin{array}{l}\text { Biotechnology } \\
\text { manufacturing, service } \\
\text { and trade }\end{array}$ & 5 & $>8$ \\
\hline $\begin{array}{l}\text { J.C. Business manager, }>15 \text { year in industry, 35- } \\
\text { 44, UG }\end{array}$ & $\begin{array}{l}\text { Biotechnology } \\
\text { manufacturing and } \\
\text { trade }\end{array}$ & 38 & $\begin{array}{l}\text { No accurate } \\
\text { figure ( }>4)\end{array}$ \\
\hline $\begin{array}{l}\text { F.C. Business manager, Bioscientist, }>15 \text { years in } \\
\text { industry, age 35-44, UG }\end{array}$ & $\begin{array}{l}\text { Biotechnology } \\
\text { manufacturing, service } \\
\text { and trade }\end{array}$ & 38 & $>15$ \\
\hline $\begin{array}{l}\text { M.T. Business manager, Bioscientist, }>20 \text { years in } \\
\text { industry, over 55, PG }\end{array}$ & $\begin{array}{l}\text { Biotechnology } \\
\text { manufacturing and } \\
\text { trade }\end{array}$ & 40 & $>200$ \\
\hline $\begin{array}{l}\text { J.C. Business manager, Bioscientist, }>10 \text { years in } \\
\text { industry, 35-44, PG }\end{array}$ & $\begin{array}{l}\text { Biotechnology } \\
\text { manufacturing, service } \\
\text { and trade }\end{array}$ & 38 & $\begin{array}{l}\text { No accurate } \\
\text { figure }(>4)\end{array}$ \\
\hline
\end{tabular}

Note: All participants' names are pseudonyms. Undergraduate Degree (UG); Postgraduate (PG); Doctoral Degree (PhD) 


\section{Appendix II}

\section{Interview guide}

General information about the firm

A brief history of the firm

A brief resume about yourself

Markets and products

Successful new products developed

About the collaborative relationships

Would you like to talk about those collaborative relationships that lasted after the commercialization of the products?

What is the process of the relationships?

How do you engage with them in the relationship process?

How do you use virtual technology? How do you use videoconferencing?

How do you use other forms of communication in the relationship process? 


\section{Appendix III}

Table 2. Examples of relationship processes in 'Engaging' with videoconferencing

\begin{tabular}{|c|c|c|c|c|}
\hline \multicolumn{2}{|c|}{ Descriptive categories } & \multicolumn{3}{|c|}{ Analytical accounts } \\
\hline Theme & Examples from raw data & Practice & Core Theme & $\begin{array}{l}\text { Managerial } \\
\text { implications }\end{array}$ \\
\hline $\begin{array}{l}\text { Patterns of } \\
\text { the } \\
\text { engagement }\end{array}$ & $\begin{array}{l}\text { "It was exciting ... very good, it } \\
\text { doesn't waste time ... it's sure to } \\
\text { beat travel..." (D, B) } \\
\text { "Video-conference you can see } \\
\text { the body language, and that gives } \\
\text { the way as much as what } \\
\text { people say, so we find it very } \\
\text { useful." (D, B) } \\
\text { "We held videoconference several } \\
\text { times weekly..." (A, H) } \\
\text { "we have videoconference at least } \\
\text { once a week." (G, C) } \\
\text { "We don't want to keep phoning } \\
\text { them (customers) up... don't want } \\
\text { to annoy them, you get so much } \\
\text { outcomes in face-face, like } \\
\text { interactiveness and richness" (P,C) }\end{array}$ & $\begin{array}{l}\text { Choice, related to } \\
\text { importance of the } \\
\text { relationship }\end{array}$ & $\begin{array}{l}\text { Emphasis on } \\
\text { the importance } \\
\text { of the } \\
\text { relationship }\end{array}$ & $\begin{array}{l}\text { VC can be risky } \\
\text { for an } \\
\text { important } \\
\text { relationship }\end{array}$ \\
\hline Cognition & $\begin{array}{l}\text { “... a lot of conferences where } \\
\text { academics papers are ...the most } \\
\text { lucrative social ...for a start, it's a } \\
\text { dialogue." (A, H) } \\
\text { “... videoconference, meeting with } \\
\text { technical experts (clients), to } \\
\text { understand the problem ...the } \\
\text { technical details." (K, C) } \\
\text { "still a bit artificial there ..." (H, B) } \\
\text { “... we wrote a proposal and } \\
\text { emailed it, went backwards and } \\
\text { forwards ..." (J, C) } \\
\text { "The decisions don't get made just } \\
\text { right away ...looking at the } \\
\text { relationship, money involved, not } \\
\text {... based on one videoconference." } \\
\text { (C, I) } \\
\text { "but we backup all these with } \\
\text { visits with customers mostly ... }\end{array}$ & $\begin{array}{l}\text { Academic } \\
\text { conferences, the } \\
\text { community, } \\
\text { Technical } \\
\text { Discussions; } \\
\text { Interactive } \\
\text { demonstrations; } \\
\text { Understand the } \\
\text { problems following } \\
\text { face-face; } \\
\text { Proposal; } \\
\text { Multidisciplinary } \\
\text { topics, complex } \\
\text { decisions and } \\
\text { critical deals; } \\
\text { Technical advice on } \\
\text { new products }\end{array}$ & $\begin{array}{l}\text { Tacit } \\
\text { knowledge; } \\
\text { Socializing } \\
\text { Participation; } \\
\text { Media richness; } \\
\text { Knowledge } \\
\text { equivocality; } \\
\text { Involvement; } \\
\text { A higher level } \\
\text { of knowledge } \\
\text { tacitness; } \\
\text { Commitment; } \\
\text { Key account; } \\
\text { Bridging social } \\
\text { capital }\end{array}$ & $\begin{array}{l}\text { Enabling } \\
\text { cognition; } \\
\text { The stage of } \\
\text { engagement } \\
\text { process } \\
\text { matters } \\
\text { An alternative } \\
\text { depends on } \\
\text { the event } \\
\text { vC is } \\
\text { insufficient; } \\
\text { not for } \\
\text { complex } \\
\text { decision } \\
\text { making; } \\
\text { Building } \\
\text { bonding social } \\
\text { capital }\end{array}$ \\
\hline
\end{tabular}




\begin{tabular}{|c|c|c|c|c|}
\hline & $\begin{array}{l}\text { much of personal relationship." (S, } \\
\text { A) }\end{array}$ & & & \\
\hline Affect & $\begin{array}{l}\text { "... a lot of conferences ... the } \\
\text { most lucrative social ... for a start, } \\
\text { it's a dialogue." (A, H) } \\
\text { "I always want to talk to them } \\
\text {...always the most important ... } \\
\text { trigger ... the relationship." (F, C) } \\
\text { “... building up the relationships ...I } \\
\text { do include some social chat, but I } \\
\text { wouldn't have that in a } \\
\text { videoconference..." (G, C) } \\
\text { “... for trust development, video- } \\
\text { conferencing would be better } \\
\text { (than email), because you can see } \\
\text { someone ... and again interactive } \\
\text { a bit more ... ultimately to meet ... } \\
\text { face-face." (B, C) } \\
\text { “... usually we keep in touch ... } \\
\text { know the person very well, almost } \\
\text { like a friend." (A, K) }\end{array}$ & $\begin{array}{l}\text { Social milieu; } \\
\text { Face-face, } \\
\text { Body gestures, eye } \\
\text { contact } \\
\text { Social conversation; } \\
\text { Inter-personal } \\
\text { knowledge } \\
\text { Building up social } \\
\text { ties; } \\
\text { VC is better than } \\
\text { email; } \\
\text { Maintaining social } \\
\text { ties }\end{array}$ & $\begin{array}{l}\text { Social and } \\
\text { community } \\
\text { context; } \\
\text { Intimacy; } \\
\text { Exchanging } \\
\text { Inter-personal } \\
\text { knowledge; } \\
\text { Media richness; }\end{array}$ & $\begin{array}{l}\text { Building } \\
\text { Bonding social } \\
\text { capital, trust } \\
\text { development } \\
\text { Face-face, } \\
\text { Social } \\
\text { networking; } \\
\text { Building \& } \\
\text { maintaining } \\
\text { friendships; }\end{array}$ \\
\hline Trust & $\begin{array}{l}\text { “... we go for a lot of conferences } \\
\text { where academics papers are, that } \\
\text { will be the most lucrative social } \\
\text {...for a start, it's a dialogue ... and } \\
\text { then ..." (A, H) } \\
\text { “... prefer to meet somebody first } \\
\text {... to understand people ... look } \\
\text { eye-to-eye ... anything else works" } \\
\text { (S, A) } \\
\text { "... this is my interest, you did this, } \\
\text { tell me more about it ... they had a } \\
\text { problem ... because I can see } \\
\text { potential applications ... we got } \\
\text { into dialogues almost } \\
\text { straightaway." (I, A) } \\
\text { “... I knew what their problems } \\
\text { were ... you tell people roughly } \\
\text { what you are going ... you are } \\
\text { honest with people ... the key } \\
\text { really ... look at their organization } \\
\text { as well ...' (S, A) } \\
\text { “... had looked at the tests we did } \\
\text { and the products ... we were } \\
\text { contacted by them." (B, C) "the } \\
\text { relationships have been built ... so } \\
\text { they were feeling very confident if } \\
\text { talked to us ..." (J, C) }\end{array}$ & $\begin{array}{l}\text { Academic } \\
\text { conferences, } \\
\text { Academic/industrial } \\
\text { knowledge } \\
\text { exchange; } \\
\text { Eye contact; } \\
\text { inter-personal } \\
\text { knowledge } \\
\text { exchange; } \\
\text { Face-face; } \\
\text { customer problems; } \\
\text { Solutions; } \\
\text { Being honest; } \\
\text { acquired knowledge } \\
\text { of individual; } \\
\text { Examine } \\
\text { oranisational facts; } \\
\text { vC useful; } \\
\text { Being confident; } \\
\text { Checking corporate } \\
\text { information }\end{array}$ & $\begin{array}{l}\text { Shared } \\
\text { bioscience } \\
\text { community, } \\
\text { Reliability; } \\
\text { Social } \\
\text { networking; } \\
\text { immediate } \\
\text { responses; } \\
\text { Referrals; } \\
\text { Intimacy; } \\
\text { Scientific } \\
\text { Knowledge- } \\
\text { linkage; } \\
\text { Tacit } \\
\text { knowledge } \\
\text { exchange; } \\
\text { VC built on } \\
\text { primary trust; } \\
\text { Empathy; } \\
\text { Quality, } \\
\text { capability, } \\
\text { credibility; } \\
\text { honesty; }\end{array}$ & $\begin{array}{l}\text { Inter-personal } \\
\text { trust; } \\
\text { blended with it } \\
\text { at an org. } \\
\text { level; } \\
\text { SMEs } \\
\text { Primary trust } \\
\text { Media } \\
\text { richness; } \\
\text { Building trust; } \\
\text { Importance of } \\
\text { trust; } \\
\text { VC is valued; } \\
\text { Capabilities on } \\
\text { the new } \\
\text { product } \\
\text { development }\end{array}$ \\
\hline
\end{tabular}




\begin{tabular}{|c|c|c|c|c|}
\hline & & & $\begin{array}{l}\text { Reduced } \\
\text { uncertainty }\end{array}$ & \\
\hline $\begin{array}{l}\text { Social } \\
\text { capital }\end{array}$ & $\begin{array}{l}\text { “... where like-minded people } \\
\text { are... we work with" (J, C) } \\
\text { “... it (VC) works better if you } \\
\text { know the people, as you know } \\
\text { their reactions and what it means" } \\
\text { (B, Cy) } \\
\text { “... so they were feeling very } \\
\text { confident if they talked to } \\
\text { someone who knew what they } \\
\text { were talking about." (J, C) } \\
\text { “... suppose professional } \\
\text { associations, we connected to a } \\
\text { few... we are member of xxx ... } \\
\text { have credibility." (B, C) “... } \\
\text { “... meeting with technical experts } \\
\text { to understand the problem, the } \\
\text { technical details" (K, C) }\end{array}$ & $\begin{array}{l}\text { Sharing individual } \\
\text { professional } \\
\text { backgrounds; } \\
\text { Referring to the } \\
\text { previous topics; } \\
\text { VC works; } \\
\text { Professional/ } \\
\text { industrial } \\
\text { associations; } \\
\text { Shared inter- } \\
\text { personal } \\
\text { knowledge; } \\
\text { Customer demand; } \\
\text { Technical details; } \\
\text { Knowing the needs; } \\
\text { Technical discussion }\end{array}$ & $\begin{array}{l}\text { Sharing inter- } \\
\text { personal } \\
\text { knowledge; } \\
\text { Commonalities; } \\
\text { Shared } \\
\text { experiences; } \\
\text { Tacit } \\
\text { knowledge } \\
\text { exchanges, } \\
\text { Identifying and } \\
\text { creating } \\
\text { bonding social } \\
\text { capital; } \\
\text { Creating } \\
\text { bridging social } \\
\text { capital; } \\
\text { Media richness }\end{array}$ & $\begin{array}{l}\text { Identifying } \\
\text { homogeneous } \\
\text { individual } \\
\text { identities and } \\
\text { characteristics; } \\
\text { VC } \\
\text { engagement } \\
\text { Participating in } \\
\text { activities } \\
\text { bridging the } \\
\text { differences } \\
\text { Identify and } \\
\text { creating } \\
\text { shared goals }\end{array}$ \\
\hline
\end{tabular}

